\title{
47. THE MINERALOGY AND GEOCHEMISTRY OF BASALT WEATHERING, HOLES 417A AND 418Å
}

\author{
Susan E. Humphris, ${ }^{1}$ R.N. Thompson, Department of Geology, Imperial College of Science and Technology, \\ Prince Consort Road, London SW7 2BP, England \\ and \\ Giselle F. Marriner, Department of Geology, Bedford College, London NW1 4NS, England
}

\section{INTRODUCTION}

The successful drilling on Legs 51,52 , and 53 created a rare opportunity to investigate the long-term effects of seawater-rock interactions on the mineralogy and chemistry of basalts erupted on the sea floor.

Holes 417A and 418A were drilled about $6.5 \mathrm{~km}$ apart in 109-m.y.-old crust (anomaly $M 0$ ) at the southern end of the Bermuda Rise. Circulation of seawater through cracks and fractures in the basaltic column at these sites has exposed large amounts of basalt to seawater over a long period of time. This has resulted in chemical reactions between the rock and seawater at low temperatures, i.e., close to those of ambient bottom water. Throughout this paper, the term "weathering" will be used to signify this process. The relatively deep basement penetration $(544 \mathrm{~m})$ and the good recovery $(72 \%)$ in Hole $418 \mathrm{~A}$ provided a stratigraphic sequence for investigation of the variation in the degree and nature of basalt weathering. The basalt recovered from Hole $417 \mathrm{~A}$ was notable for its very high degree of weathering, particularly in the upper basement cores.

The purpose of this paper is to describe the weathering of the basalts in terms of the changes in their mineralogy and chemistry, and to compare the weathering observed in Hole $418 \mathrm{~A}$ with that in the upper parts of Hole $417 \mathrm{~A}$. Eleven highly weathered samples were made available to us from Hole 417A, and these covered an interval from 208 to 280 meters below the sea floor. A suite of samples from Hole $418 \mathrm{~A}$ was also obtained; these represent the complete recovery of the stratigraphic sequence, i.e., from 320 to 868 meters sub-bottom.

\section{WEATHERING MINERALOGY}

\section{General Description}

The sequence of basalt that forms the upper part of Hole $417 \mathrm{~A}$ is highly oxidized and weathered and consists of pillow lavas separated by volcanic breccia.

The pillow basalt fragments are plagioclase phyric with about 10 per cent plagioclase phenocrysts. However, almost all have been weathered to alkali feldspar, clay minerals, or carbonate. Many of the altered feldspars are replaced only around the edges, leaving holes inside the phenocrysts.

\footnotetext{
${ }^{1}$ Present address: Lamont-Doherty Geological Observatory, Palisades, New York.
}

Brown pseudomorphs of olivine are a minor component (usually $<3 \%$ ). Veins appear to have dominantly controlled the weathering of the groundmass, which changes from gray in the fresher portions of the rock to orange-brown adjacent to the veins. Vesicles are rare $(<1 \%)$ and both these and the veins are filled with secondary minerals including calcite, clay minerals, and iron oxides. The veins are of variable thickness, and one calcite vein (up to $0.75 \mathrm{~cm}$ wide) contains small fragments of fairly fresh wallrock, and angular glass shards that are partially weathered to clays (Plate 1).

The volcanic breccia is made up of large (up to $5 \mathrm{~cm}$ long) basaltic pillow fragments, and small (about 2 to 3 $\mathrm{mm}$ ) green and brown aggregates of secondary minerals. These are cemented together by a matrix of calcite, clay minerals, and hematite (Plate 2). The basaltic pillow fragments are highly weathered and vary from orange-brown in the interiors to dark brown around the edges. The olivine and plagioclase phenocrysts are all replaced by secondary minerals, and the groundmass is oxidized. These fragments are commonly cross-cut by veins of calcite, some of which penetrate into the cementing matrix. The smaller fragments exhibit a very delicate "agate-like" structure, being concentrically zoned with alternating bands of green and brown clay minerals. They tend to occur in aggregates adjacent to the fragments of pillow basalt, and may represent completely weathered glassy margins. The cementing matrix is pale green and white, and consists chiefly of calcite and clay minerals. Bright red iron oxides form a network of veinlets throughout the matrix.

The suite of basalts from Hole 418A are fresher than those from Hole 417A, but all of them show some degree of weathering. Calcite and clay minerals are the main alteration products, but generally they do not exceed 20 per cent of the basalt. Calcite-clay minerals-pyrite weathering appears to have been the pervasive type of alteration throughout the sequence, while oxidation is more localized and appears to be related to cracks and brecciated zones. The pillow basalts are sparsely to moderately phyric containing mainly plagioclase phenocrysts (up to $10 \%$ ), olivine phenocrysts (1 to $3 \%$ ), and sometimes clinopyroxene phenocrysts $(<1$ to $2 \%)$. The olivine phenocrysts in all the samples are weathered to associations of clay minerals, calcite, and pyrite. Many of the plagioclase phenocrysts are quite fresh, but sometimes discolored to bright yellow by alteration along cleavages. In the more weathered samples and adjacent to fractures, they are partially replaced by 
potassium feldspar or calcite. Clinopyroxene, both as phenocrysts and in the groundmass, is fresh throughout the sequence. Examples of microprobe analyses of fresh plagioclase, clinopyroxene, and olivine are presented in Table 1. The groundmass is generally gray, but is patchily replaced by brown and green clay minerals, sometimes with associated calcite. Glass is usually devitrified and commonly palagonitized. Vesicles constitute up to 3 per cent of the rock and are filled with calcite, or zoned green and brown clay minerals, or both. Veins are common throughout the sequence and are often dark green to black and very hard. They are filled with calcite, clay minerals, zeolites, quartz, and opaque minerals in various combinations. Secondary opaque minerals occur throughout the hole, the most abundant being sulfides. Iron oxides and hydroxides are restricted to specific depth intervals within the core.

\section{Clay Minerals}

Clay minerals are the most abundant weathering products in Hole $417 \mathrm{~A}$ and constitute the dominant matrix mineral in the breccias. In the weathered basaltic pillow fragments, green to brown, hard, fine-grained aggregates, pseudomorph olivine, and occasionally plagioclase phenocrysts and also replace glass. Vesicles are filled with green and/or brown clay minerals. Veins consisting of both green and brown clay minerals, together with iron oxides are also observed. Examples of microprobe analyses of these clay minerals using a defocused beam indicate that both green and brown varieties are rich in $\mathrm{FeO}^{*}$ and $\mathrm{K}_{2} \mathrm{O}$ (Table 2).

TABLE 1A

Microprobe Analyses of Fresh Phenocrysts From Hole 418A

\begin{tabular}{|c|c|c|c|c|c|}
\hline \multirow{2}{*}{$\begin{array}{c}\text { Oxide } \\
\text { (wt. \%) }\end{array}$} & \multicolumn{5}{|c|}{ Plagioclase } \\
\hline & 1 & 2 & 3 & 4 & 5 \\
\hline $\mathrm{SiO}_{2}$ & 47.40 & 50.07 & 49.36 & 48.06 & 50.95 \\
\hline $\mathrm{Al}_{2} \mathrm{O}_{3}$ & 33.26 & 31.21 & 32.11 & 32.87 & 30.64 \\
\hline $\mathrm{FeO} *$ & 0.30 & 0.40 & 0.43 & 0.41 & 0.78 \\
\hline $\mathrm{MgO}$ & n.d. & n.d. & 0.21 & 0.21 & n.d. \\
\hline $\mathrm{CaO}$ & 17.54 & 15.46 & 15.30 & 16.25 & 14.14 \\
\hline $\mathrm{Na}_{2} \mathrm{O}$ & 1.33 & 2.36 & 2.37 & 2.05 & 2.76 \\
\hline \multirow[t]{2}{*}{ Total } & 99.83 & 99.50 & 99.78 & 99.85 & 99.27 \\
\hline & \multicolumn{5}{|c|}{ Cations per 32 oxygens } \\
\hline $\mathrm{Si}$ & 8.72 & 9.18 & 9.03 & 8.82 & 9.33 \\
\hline $\mathrm{Al}$ & 7.21 & 6.75 & 6.93 & 7.11 & 6.62 \\
\hline $\mathrm{Fe}$ & 0.05 & 0.06 & 0.07 & 0.06 & 0.12 \\
\hline $\mathrm{Mg}$ & - & - & 0.06 & 0.06 & - \\
\hline $\mathrm{Ca}$ & 3.46 & 3.04 & 3.00 & 3.20 & 2.78 \\
\hline $\mathrm{Na}$ & 0.47 & 0.84 & 0.84 & 0.73 & 0.98 \\
\hline Total & 19.91 & 19.87 & 19.93 & 19.98 & 19.83 \\
\hline
\end{tabular}

Note: $\mathrm{FeO}^{*}=$ total iron as $\mathrm{FeO}$; n.d. $=$ not detected. $\mathrm{K}_{2} \mathrm{O}$ was not detected. $1=$ phenocryst, Sample 418A-19-5, 42-46 cm (\#1E); 2 = large, euhedral phenocryst, Sample 418A-33-2, $124 \mathrm{~cm}$ (\#7B); 3 = euhedral phenocryst, Sample 418A-52-4, 75$80 \mathrm{~cm}(\# 6 \mathrm{~A}) ; 4=$ euhedral phenocryst, Sample 418A-71-3, 101-104 cm (\#7); 5 = plagioclase in subophitic glomerocryst with pyroxene, Sample 418A-71-3, 101-104 cm (\#7).
TABLE 1B

\begin{tabular}{lrrrr}
\hline $\begin{array}{c}\text { Oxide } \\
\text { (wt. \%) }\end{array}$ & \multicolumn{1}{c}{6} & \multicolumn{1}{c}{7} & \multicolumn{1}{c}{8} & \multicolumn{1}{c}{9} \\
\hline $\mathrm{SiO}_{2}$ & 54.16 & 53.95 & 52.32 & 52.29 \\
$\mathrm{Al}_{2} \mathrm{O}_{3}$ & 1.70 & 1.92 & 3.82 & 3.65 \\
$\mathrm{FeO}^{*}$ & 6.36 & 5.91 & 7.22 & 7.05 \\
$\mathrm{MgO}$ & 18.55 & 17.75 & 17.35 & 16.96 \\
$\mathrm{CaO}$ & 19.15 & 18.80 & 18.71 & 18.53 \\
$\mathrm{TiO}_{2}$ & 0.33 & 0.33 & 0.63 & 0.59 \\
$\mathrm{MnO}_{\mathrm{Cr}} \mathrm{O}_{3}$ & 0.14 & 0.25 & 0.19 & 0.13 \\
$\mathrm{Total}$ & 0.35 & 0.28 & 0.32 & 0.34 \\
& 100.74 & 99.19 & 100.56 & 99.54 \\
& \multicolumn{5}{c}{ Cations per } & & & \\
$\mathrm{Si}$ & 1.96 & 1.98 & 1.91 & 1.92 \\
$\mathrm{Al}$ & 0.07 & 0.08 & 0.16 & 0.16 \\
$\mathrm{Fe}$ & 0.19 & 0.18 & 0.22 & 0.22 \\
$\mathrm{Mg}$ & 1.00 & 0.97 & 0.94 & 0.93 \\
$\mathrm{Ca}$ & 0.74 & 0.74 & 0.73 & 0.73 \\
$\mathrm{Ti}$ & 0.01 & 0.01 & 0.02 & 0.02 \\
$\mathrm{Mn}$ & 0.004 & 0.01 & 0.01 & 0.004 \\
$\mathrm{Cr}$ & 0.01 & 0.01 & 0.01 & 0.01 \\
$\mathrm{Total}$ & 3.984 & 3.98 & 4.00 & 3.994 \\
\hline $\mathrm{Note}$ & & & &
\end{tabular}

Note: $\mathrm{K}_{2} \mathrm{O}$ and $\mathrm{Na}_{2} \mathrm{O}$ were not detected. $6=$ euhedral phenocryst; $7=$ subhedral, slightly rounded phenocryst; $8=$ pyroxene in glomerocryst with plagioclase; $9=$ pyroxene in glomerocryst. All analyses (6-9) from Sample 418A-71-3, 101-104 cm (\#7).

TABLE 1C

\begin{tabular}{lccccc}
\hline $\begin{array}{c}\text { Oxide } \\
\text { (wt. \%) }\end{array}$ & \multicolumn{1}{c}{ 1 } & \multicolumn{5}{c}{ Olivine } \\
\hline $\mathrm{SiO}_{2}$ & 40.32 & 40.36 & 40.14 & 39.65 & 39.39 \\
$\mathrm{FeO}^{*}$ & 12.12 & 14.15 & 14.64 & 16.74 & 17.27 \\
$\mathrm{MnO}$ & 0.12 & n.d. & 0.23 & 0.18 & 0.22 \\
$\mathrm{MgO}$ & 47.43 & 45.64 & 45.30 & 43.36 & 42.99 \\
$\mathrm{NiO}$ & 0.36 & 0.17 & 0.20 & n.d. & 0.17 \\
$\mathrm{CaO}$ & 0.28 & 0.22 & 0.30 & 0.29 & 0.26 \\
$\mathrm{Total}$ & 100.63 & 100.54 & 100.81 & 100.22 & 100.30 \\
& \multicolumn{5}{c}{$\mathrm{Cations}$ per 4 oxygens } \\
$\mathrm{Si}$ & 0.99 & 1.00 & 1.00 & 1.00 & 1.00 \\
$\mathrm{Fe}$ & 0.25 & 0.29 & 0.31 & 0.35 & 0.37 \\
$\mathrm{Mn}$ & 0.002 & - & 0.01 & 0.004 & 0.01 \\
$\mathrm{Mg}$ & 1.74 & 1.69 & 1.68 & 1.63 & 1.62 \\
$\mathrm{Ni}$ & 0.01 & 0.003 & 0.004 & - & 0.003 \\
$\mathrm{Ca}$ & 0.01 & 0.01 & 0.01 & 0.01 & 0.01 \\
$\mathrm{Total}$ & 3.002 & 2.993 & 3.014 & 2.994 & 3.013 \\
\hline
\end{tabular}

Note: $\mathrm{FeO}^{*}=$ total iron as $\mathrm{FeO}$; n.d. $=$ not detected. $1=$ center of large euhedral phenocryst, Sample $418 \mathrm{~A}-46-1,25-30 \mathrm{~cm}$ (\#2A); 2 = euhedral phenocryst, Sample 418A-49-1, 135-139 cm (\#6E); 3 = large, euhedral phenocryst, Sample 418A-51-3, $122-126 \mathrm{~cm}$ (\#6B); 4 = phenocryst, Sample 418A-73-3, 2-9 $\mathrm{cm}(\# 1) ; 5$ = large euhedral phenocryst, Sample 418A-24-1, 9-12 cm (\#2A). 
There is no variation in composition with the site of formation of the clay mineral; it pseudomorphs olivine as well as replacing the groundmass and filling veins and vesicles. The structural formulas, calculated for 22 oxygens, which allows 2 oxygen equivalents for the 4 hydroxyls, indicate an average formula of: $\left(\mathrm{K}_{1.42} \mathrm{NatrCa}_{1.14}\right)_{1.56}$ ( $\left.\mathrm{Si} 7.67 \mathrm{Al}_{0.33}\right)_{8}\left(\mathrm{Al}_{0.82} \mathrm{Fe}_{3.12} \mathrm{Mg}_{0.92}\right)_{4.86} \mathrm{O}_{20}(\mathrm{OH})_{4} \mathrm{nH}_{2} \mathrm{O}$, which most closely resembles celadonite.

The matrices of the breccias from Hole $417 \mathrm{~A}$, including the fragments that exhibit the "agate-like"' structure, were separated for X-ray diffraction studies. The chief mineral identified was a smectite. Glycerol saturation of oriented mounts gave expansion from approximately $14 \AA$ to between 17.68 and $17.99 \AA$; heating to $400^{\circ} \mathrm{C}$ caused collapse of the basal spacing to between 9.96 and $10.20 \AA$. Optically, this smectite consists of pale green, fine-grained platy aggregates which are much softer than the celadonite. No reliable microprobe analyses of this phase were obtained because the matrix could not be evenly polished. However, in appearance it is very similar to the smectite observed in Hole $418 \mathrm{~A}$. In addition to this smectite, celadonite was also identified, but appears to be poorly developed and not as abundant in the matrix as the smectite. X-ray data for the celadonite are given in Table 3 , and the major peaks are clearly distinguishable. However, the 001 peak is quite diffuse, and is best seen after the smectite 001 peak has been expanded with glycerol.

In Hole $418 \mathrm{~A}$, green and brown clay minerals are also the most abundant secondary products. The bright green mineral is fine grained and hard, and the brown mineral is platy and ranges from pale yellow-brown to dark brown. Olivine phenocrysts are pseudomorphed by (1) brown clay minerals; (2) fine-grained intergrowths of brown clay minerals usually with calcite; (3) mixtures of bright green and brown clay minerals; and (4) occasionally by bright green clay minerals. All of these pseudomorphs may occur in a single sample. In general, the plagioclase phenocrysts are not replaced by clays. In the more highly weathered samples, patches of brown and green clay minerals, sometimes with associated calcite, occur within the groundmass. Vesicles are very often infilled with clay minerals, and color zonation within a single vesicle is a common feature. The most abundant types of clay mineral vesicle fillings are either light brown or bright green clay minerals, sometimes with associated calcite. The larger vesicle fillings show zoning from bright green rims to dark brown cores.

This zonation is also observed in the veins in Hole 418A. However, there are two types of green clay minerals that occur in the veins. The first is the bright green mineral which is hard and appears to be the same as that replacing

TABLE 2

Defocused Microprobe Analyses of Clay Minerals, Holes 417A and 418A

\begin{tabular}{|c|c|c|c|c|c|c|c|c|c|c|c|c|c|c|c|}
\hline \multirow{2}{*}{$\begin{array}{c}\text { Oxide } \\
\text { (wt. \%) }\end{array}$} & \multicolumn{8}{|c|}{ Hole $417 \mathrm{~A}$} & \multicolumn{7}{|c|}{ Hole 418A } \\
\hline & 1 & 2 & 3 & 4 & 5 & 6 & 7 & 8 & 9 & 10 & 11 & 12 & 13 & 14 & 15 \\
\hline $\mathrm{SiO}_{2}$ & 47.26 & 49.33 & 49.35 & 49.28 & 45.54 & 49.38 & 50.00 & 47.84 & 50.29 & 50.94 & 52.22 & 50.09 & 50.71 & 46.42 & 46.83 \\
\hline $\mathrm{Al}_{2} \mathrm{O}_{3}$ & 7.70 & 4.85 & 5.20 & 5.99 & 9.17 & 4.97 & 3.64 & 7.65 & 3.15 & 4.98 & 1.89 & 4.39 & 3.22 & 6.93 & 6.95 \\
\hline $\mathrm{FeO}^{*}$ & 22.58 & 24.79 & 25.13 & 25.29 & 22.93 & 23.17 & 22.73 & 22.39 & 18.41 & 22.62 & 23.12 & 11.68 & 23.48 & 15.22 & 14.91 \\
\hline $\mathrm{MgO}$ & 3.73 & 3.46 & 3.20 & 3.27 & 3.32 & 4.52 & 5.06 & 4.77 & 14.50 & 3.90 & 6.09 & 20.36 & 5.31 & 17.69 & 17.34 \\
\hline $\mathrm{CaO}$ & 2.24 & 0.43 & 0.50 & 0.73 & 0.67 & 0.30 & 0.44 & 1.54 & 1.20 & 0.74 & 0.39 & 1.32 & 0.58 & 2.49 & 1.96 \\
\hline $\mathrm{Na}_{2} \mathrm{O}$ & 0.51 & n.d. & n.d. & n.d. & n.d. & n.d. & n.d. & 0.45 & 0.54 & n.d. & n.d. & 0.38 & n.d. & 0.40 & 0.38 \\
\hline $\mathrm{K}_{2} \mathrm{O}$ & 6.33 & 7.28 & 7.25 & 6.99 & 6.71 & 7.93 & 7.64 & 6.46 & 1.52 & 7.41 & 7.66 & 0.18 & 7.55 & 0.12 & 0.09 \\
\hline Total & 90.35 & 90.14 & 90.63 & 91.55 & 88.34 & 90.27 & 89.51 & 91.10 & 89.61 & 90.59 & 91.37 & 88.40 & 90.85 & 89.27 & 88.46 \\
\hline
\end{tabular}

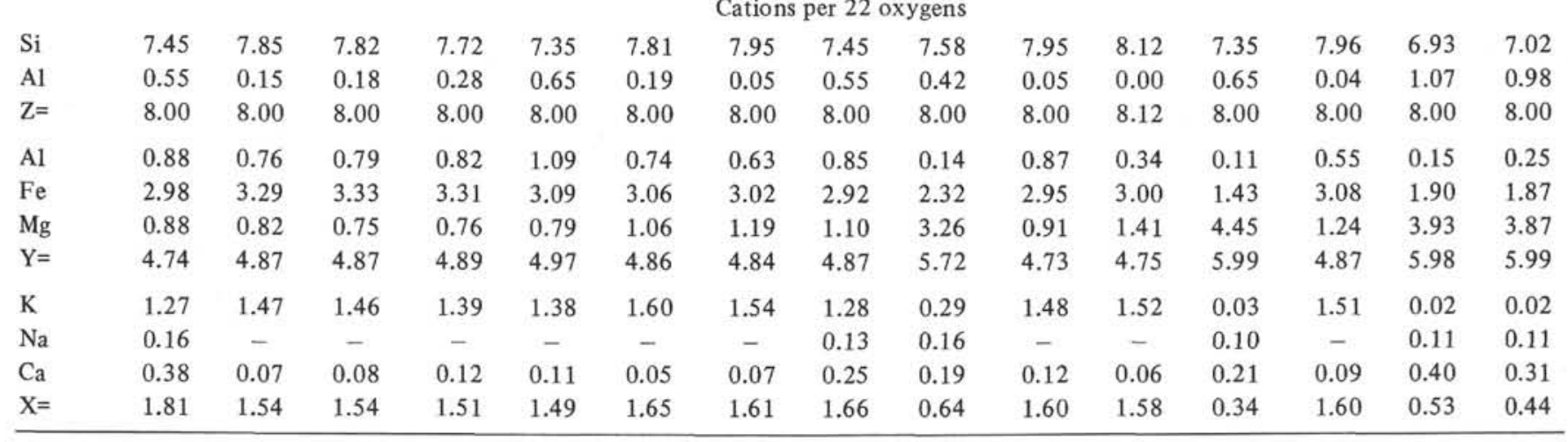

Note: $\mathrm{FeO}^{*}=$ total iron expressed as $\mathrm{FeO} ;$ n.d. = not detected; $\mathrm{TiO}_{2}$ and $\mathrm{MnO}$ were not detected. 1 = green vein filling, $\mathrm{Sample} 417 \mathrm{~A}-28-4$, 54-57 cm; 2 = green zone of groundmass weathering, Sample 417A-23-1, 118-120 cm; 3 = green vesicle filling, Sample 417A-23-1, 118-120 $\mathrm{cm} ; 4=$ green pseudomorph after olivine phenocryst, Sample $417 \mathrm{~A}-23-1,118-120 \mathrm{~cm} ; 5=$ green clay mineral lining vesicle subsequently filled with calcite, Sample 417A-26-5, 41-45 cm; 6 = green vesicle filling, Sample 417A-28-4, 54-57 cm; 7 = brown vein filling, Sample 417A$29-3,136-138 \mathrm{~cm} ; 8$ = dark brown vesicle filling, Sample 417A-28-4, 54-57 cm; 9 = brown pseudomorph after olivine phenocryst, Sample $418 \mathrm{~A}-19-5,42-46 \mathrm{~cm}$ (\#1E); 10 = green mineral infilling vug, Sample 418A-33-2, $124 \mathrm{~cm}(\# 7 \mathrm{~B}) ; 11=$ green clay mineral infilling vug, Sample 418A-52-4, 75-80 cm (\#6A); 12 = brown pseudomorph after olivine phenocryst, Sample 418A-52-4, 75-80 cm (\#6A); $13=$ green vesicle filling, Sample 418A-52-4, 75-80 cm (\#6A); 14 = brown vesicle filling, Sample 418A-71-3, 101-104 cm (\#7); $15=$ brown smectite with calcite replacing phenocryst, Sample 418A-71-3, 101-104 cm (\#7). 
TABLE 3

X-Ray Diffraction Data for "Celadonite" From the Matrix of Breccias, Hole 417A

\begin{tabular}{ccc}
\hline hkl. & $\mathrm{d}(\AA)$ & Intensity \\
\hline 001 & 9.965 & $\mathrm{~m}$ (diffuse) \\
020 & 4.525 & vs \\
003 & 3.316 & $\mathrm{~m}$ \\
112 & 3.095 & $\mathrm{~m}$ \\
$13 \overline{1}$ & 2.584 & vs (broad) \\
$13 \overline{2}$ & 2.393 & $\mathrm{~m}$ (broad) \\
060 & 1.507 & $\mathrm{~m}$ (broad) \\
\hline
\end{tabular}

groundmass minerals. The second is a pale green to brown, fine-grained, soft mineral which optically resembles the brown clay minerals that pseudomorph olivine. There are many monomineralic veins as well as complex veins in which the clay minerals are intermixed, but the sequence observed most commonly in zoned veins is bright green clays $\rightarrow$ brown clays $\rightarrow$ zeolite or quartz or calcite. Further substantive evidence for this sequence of formation is provided by calcite veins which often cross-cut clay minerals replacing groundmass. Several thick veins that appear very dark green to black in hand specimen were separated for X-ray diffraction studies. These consisted of either calcite + smectite or calcite + smectite + quartz. Oriented samples of the smectite gave an 060 peak of $1.532 \AA$, indicating a trioctahedral smectite. Glycerol saturation and heating gave expansion and collapse of the basal spacing similar to that observed for the Hole 417A smectite in the breccia matrix.

Microprobe analyses of these clay minerals are reported in Table 2 for different sites of formation. In addition, examples of chemical analyses across zoned vesicle fillings are presented in Table 4. Variations in composition of clay minerals cannot be correlated with their sites of formation. $\mathrm{SiO}_{2}$ and $\mathrm{Al}_{2} \mathrm{O}_{3}$ concentrations show minor variations, but generally their sum is between 49 and 54 weight per cent. The bright green clay mineral replacing the groundmass and infilling vesicles, is rich in $\mathrm{FeO}^{*}$ and $\mathrm{K}_{2} \mathrm{O}$, and has an average structural formula of: $\left(\mathrm{K}_{1.44} \mathrm{Ca} 0.09\right){ }_{1.53}\left(\mathrm{Si} 7.99 \mathrm{Al}_{0.01}\right)_{8}$ ( $\left.\mathrm{Al}_{0.48} \mathrm{Fe}_{2.70} \mathrm{Mg}_{1.40}\right)_{4.58} \mathrm{O}_{20}(\mathrm{OH}){ }_{4} . \mathrm{nH}_{2} \mathrm{O}$, which is similar to that of the celadonite identified in Hole 417A. This mineral has slightly higher $\mathrm{K}_{2} \mathrm{O}$ contents than the $\mathrm{K}$ and Fe-rich smectites reported from Leg 37 (Andrews et al., 1977; Robinson et al., 1977). The brown mineral replacing olivine and infilling vesicles, which is similar to the pale green vein mineral, has an average structural formula of: ( $\mathrm{Si} 7.20 \mathrm{Al}$. 80 ) 8 $\left(\mathrm{Al}_{0.13} \mathrm{Fe}_{1.60} \mathrm{Mg}_{4.30}\right)_{6.03}\left(\mathrm{~K}_{0.07} \mathrm{Natr}_{\mathrm{t}} \mathrm{Ca} 0.23\right) \quad{ }_{0.30} \mathrm{O}_{20}(\mathrm{OH})_{4} \cdot \mathrm{nH}_{2} \mathrm{O}$. It is a trioctahedral smectite and is intermediate in composition. It most closely resembles a saponite, although it is clearly an Fe-enriched variety. It is similar in composition to the saponites found in weathered basalts from the Peru Trench (Scheidegger and Stakes, 1977), but more Fe-rich than those from Leg 37 (Robinson et al., 1977). The variation in color of this Fe-rich saponite may be related to its oxidation state and may not be indicative of a compositional difference. It should be noted that in contrast with Hole $417 \mathrm{~A}$, olivine is dominantly pseudomorphed by the saponite rather than the celadonite.

The analyses of the vesicle fillings indicate that the $\mathrm{MgO} / \mathrm{FeO}^{*}$ ratio increases while the $\mathrm{K}_{2} \mathrm{O}$ content decreases from rim to core, with most of the elements showing a sharp step in abundance with the change in mineralogy. This indicates that crystallization of celadonite changed various components in the fluid, as shown by the within-zone chemical variations, and this resulted in the replacement of celadonite formation by the precipitation of saponite. This introduced the step observed for many of the elements; however, the progressive margin to center chemical trends shown by the analyses suggest a smoothly evolving fluid composition.

\section{Carbonates}

In both Holes 417A and 418A, carbonation has been an important weathering process. In Hole $417 \mathrm{~A}$, calcite occurs mainly in veins that cross-cut the weathered basaltic fragments, and in the breccia matrix, where it is associated with the brown and green clay minerals. It also fills vesicles and replaces phenocrysts, and microprobe analyses (Table 5) indicate that the calcite is relatively pure. All olivine phenocrysts are completely weathered and are often replaced by an intimate mixture of clays and calcite. Plagioclase phenocrysts are sometimes replaced by calcite and, at the very top of the hole, they are incompletely replaced by a Mn-rich carbonate (Table 5) that appears pinkish brown in thin section. The average formula of these carbonates is $\left(\mathrm{Mn}_{41.1} \mathrm{Ca} 57.3 \mathrm{Mg}_{1.6}\right) \mathrm{CO}_{3}$. Holes are often present inside the phenocrysts, indicating that the plagioclase was extensively leached during weathering; hence, they provided a site for the precipitation of secondary minerals from the reacting fluid.

$\mathrm{Li}$ et al. (1969) reported that for the reaction:

$$
\mathrm{Mn}^{2+}+\mathrm{CO}_{3}^{2-}=\mathrm{MnCO}_{3}
$$

at $0^{\circ} \mathrm{C}$ and 380 bars:

$$
\begin{gathered}
\mathrm{K}_{\mathrm{sp}}=2 \times 10^{-10} \\
\gamma_{\mathrm{Mn}^{2+}}=0.22 \\
\gamma_{\mathrm{CO}_{3}{ }^{2-}}=0.039
\end{gathered}
$$

The total carbonate concentration in sea water is about $2.7 \times 10^{-4} \mathrm{M}$, but only about 10 per cent is in the free-ion form (Garrels and Christ, 1965), i.e., $\left[\mathrm{CO}_{32}\right]_{\text {frec-ion }}=2.7<$ $10^{-5}$

Hence, solving the equation:

$$
\mathrm{K}_{\mathrm{sp}}=\gamma_{\mathrm{Mn}^{2+}}\left[\mathrm{Mn}^{2+}\right] \cdot \gamma_{\mathrm{CO}_{3}}{ }^{2-\left[\mathrm{CO}_{3}{ }^{2-}\right]}
$$

for sea water carbonate concentrations, the amount of manganese in solution in equilibrium with $\mathrm{MnCO}_{3}$ is $8.6 \times$ $10^{-4} \mathrm{M}$. Typical sea water concentrations of manganese are on the order of $4 \times 10^{-8} \mathrm{M}$; hence, sea water is highly undersaturated with respect to $\mathrm{MnCO}_{3}$. This suggests that to form Mn-rich carbonates during weathering, increased concentrations of both $\mathrm{Mn}^{2+}$ and $\mathrm{CO}_{3}{ }^{2-}$ in the circulating fluid are necessary.

In Hole 418A, calcite occurs throughout the sequence. Olivine phenocrysts are pseudomorphed by calcite with associated pyrite, and in the most highly weathered samples, 
TABLE 4

Defocussed Microprobe Analyses of Zoned Vesicle Fillings From Hole 418A

\begin{tabular}{|c|c|c|c|c|c|c|c|c|c|c|c|c|}
\hline \multirow{2}{*}{$\begin{array}{c}\text { Oxide } \\
\text { (wt. \%) }\end{array}$} & \multicolumn{4}{|c|}{$418 \mathrm{~A}-30-3,35-38 \mathrm{~cm}(\# 1 \mathrm{C})$} & \multirow[b]{2}{*}{$5 \mathrm{~A}$} & \multicolumn{4}{|c|}{$418 \mathrm{~A}-52-4,75-80 \mathrm{~cm}(\# 6 \mathrm{~A})$} & \multicolumn{3}{|c|}{$418 \mathrm{~A}-60-1,117-121 \mathrm{~cm}(\# 2 \mathrm{C})$} \\
\hline & $1 \mathrm{~A}$ & $2 \mathrm{~A}$ & $3 \mathrm{~A}$ & $4 \mathrm{~A}$ & & 1B & 2B & $3 \mathrm{~B}$ & $4 \mathrm{~B}$ & $1 \mathrm{C}$ & $2 \mathrm{C}$ & $3 \mathrm{C}$ \\
\hline $\mathrm{SiO}_{2}$ & 50.27 & 52.36 & 45.32 & 45.39 & 44.54 & 49.85 & 50.63 & 50.13 & 45.53 & 49.47 & 50.19 & 45.63 \\
\hline $\mathrm{Al}_{2} \mathrm{O}_{3}$ & 2.17 & 1.72 & 3.92 & 4.11 & 4.03 & 3.11 & 3.13 & 3.50 & 5.23 & 2.42 & 2.88 & 5.46 \\
\hline $\mathrm{FeO}^{*}$ & 24.86 & 20.33 & 10.31 & 10.34 & 9.55 & 24.91 & 21.99 & 20.69 & 12.61 & 25.37 & 20.16 & 14.12 \\
\hline $\mathrm{MgO}$ & 3.94 & 7.86 & 18.35 & 18.55 & 19.30 & 4.99 & 6.93 & 8.29 & 18.22 & 4.08 & 8.23 & 18.27 \\
\hline $\mathrm{CaO}$ & 0.56 & 0.40 & 0.87 & 0.95 & 1.06 & 0.67 & 0.59 & 0.64 & 1.16 & 0.73 & 0.67 & 1.61 \\
\hline $\mathrm{K}_{2} \mathrm{O}$ & 7.52 & 7.30 & 0.99 & 0.78 & 0.16 & 7.38 & 7.37 & 6.74 & 0.56 & 6.75 & 6.04 & n.d. \\
\hline \multirow[t]{2}{*}{ Total } & 89.32 & 89.97 & 79.76 & 80.12 & 78.64 & 90.91 & 90.64 & 89.99 & 83.31 & 88.82 & 88.17 & 85.08 \\
\hline & \multicolumn{12}{|c|}{ Cations per 22 oxygens } \\
\hline $\mathrm{Si}$ & 8.10 & 8.14 & 7.38 & 7.35 & 7.30 & 7.89 & 7.91 & 7.82 & 7.18 & 8.03 & 7.94 & 7.09 \\
\hline $\mathrm{Al}$ & 0.00 & 0.00 & 0.62 & 0.65 & 0.70 & 0.11 & 0.09 & 0.18 & 0.82 & 0.00 & 0.06 & 0.91 \\
\hline$Z=$ & 8.10 & 8.14 & 8.00 & 8.00 & 8.00 & 8.00 & 8.00 & 8.00 & 8.00 & 8.03 & 8.00 & 8.00 \\
\hline $\mathrm{Al}$ & 0.41 & 0.31 & 0.13 & 0.13 & 0.08 & 0.47 & 0.49 & 0.46 & 0.15 & 0.46 & 0.48 & 0.09 \\
\hline $\mathrm{Fe}$ & 3.35 & 2.64 & 1.40 & 1.40 & 1.31 & 3.30 & 2.87 & 2.70 & 1.66 & 3.44 & 2.66 & 1.83 \\
\hline $\mathrm{Mg}$ & 0.95 & 1.82 & 4.45 & 4.47 & 4.71 & 1.18 & 1.61 & 1.93 & 4.28 & 0.99 & 1.94 & 4.23 \\
\hline $\mathrm{Y}=$ & 4.71 & 4.77 & 5.98 & 6.00 & 6.10 & 4.95 & 4.97 & 5.09 & 6.09 & 4.89 & 5.08 & 6.15 \\
\hline $\mathrm{K}$ & 1.55 & 1.45 & 0.21 & 0.16 & 0.03 & 1.49 & 1.47 & 1.34 & 0.11 & 1.40 & 1.22 & - \\
\hline $\mathrm{Ca}$ & 0.09 & 0.07 & 0.15 & 0.16 & 0.18 & 0.11 & 0.10 & 0.11 & 0.20 & 0.13 & 0.11 & 0.27 \\
\hline $\mathrm{X}=$ & 1.64 & 1.52 & 0.36 & 0.32 & 0.21 & 1.60 & 1.57 & 1.45 & 0.31 & 1.53 & 1.33 & 0.27 \\
\hline
\end{tabular}

Note: $\mathrm{FeO}^{*}=$ total iron expressed as $\mathrm{FeO}$; n.d. = not detected; $\mathrm{Na}_{2} \mathrm{O}, \mathrm{MnO}$, and $\mathrm{TiO}_{2}$ were not detected; analysis numbers increase towards vesicle centers. $1 \mathrm{~A}=$ outer bright green rim; $2 \mathrm{~A}=$ inner green ring; $3 \mathrm{~A}$ and $4 \mathrm{~A}=$ light brown concentric zone; $5 \mathrm{~A}$ = dark brown center of vesicle. $1 \mathrm{~B}, 2 \mathrm{~B}$, and $3 \mathrm{~B}=$ wide, outer green rim of vesicle; $4 \mathrm{~B}=$ dark brown central zone. $1 \mathrm{C}=$ outer green rim; $2 \mathrm{C}=$ darker green concentric zone; $3 \mathrm{C}=$ dark brown central zone.

TABLE 5

Defocussed Microprobe Analyses of Carbonate Minerals

\begin{tabular}{|c|c|c|c|c|c|c|c|c|c|}
\hline \multirow{2}{*}{$\begin{array}{c}\text { Oxide } \\
\text { (wt. \%) }\end{array}$} & \multicolumn{6}{|c|}{ Hole 417A } & \multicolumn{3}{|c|}{ Hole $418 \mathrm{~A}$} \\
\hline & 1 & 2 & 3 & 4 & 5 & 6 & 7 & 8 & 9 \\
\hline $\mathrm{CaO}$ & 56.99 & 55.74 & 55.43 & 32.68 & 34.14 & 31.84 & 55.29 & 54.48 & 53.50 \\
\hline $\mathrm{MgO}$ & 0.28 & 0.83 & 0.29 & 1.16 & 1.06 & 1. & 2.56 & 2.59 & 2.36 \\
\hline $\mathrm{FeO}^{*}$ & n.d. & n.d. & n.d. & 0.20 & 0.31 & 0.25 & 1.36 & 1.25 & 1.35 \\
\hline $\mathrm{MnO}$ & n.d. & n.d. & 0.35 & 21.75 & 20.35 & 23.14 & 0.48 & 0.48 & 0.35 \\
\hline Total & 57.27 & 56.57 & 56.07 & 55.79 & 55.86 & 56.37 & 59.69 & 58.80 & 57.36 \\
\hline
\end{tabular}

Note: $\mathrm{FeO}^{*}=$ total iron as $\mathrm{FeO} ;$ n.d. $=$ not detected. $1=$ calcite infilling vesicle, Sample $417 \mathrm{~A}-26-5,41-45 \mathrm{~cm} ; 2=$ calcite infilling vesicle lined with green clay mineral (see Table 2, analysis 5), Sample $417 \mathrm{~A}-26-5,41-45 \mathrm{~cm} ; 3=$ calcite replacing feldspar phenocryst, Sample $417 \mathrm{~A}-26-5,41-45 \mathrm{~cm} ; 4=$ manganoan carbonate replacing feldspar phenocryst, Sample 417A-23-1, 118-120 cm;5 = manganoan carbonate replacing feldspar phenocryst, Sample $417 \mathrm{~A}-23-1,118-120 \mathrm{~cm} ; 6=$ manganoan carbonate replacing feldspar phenocryst, Sample $417 \mathrm{~A}-23-1,118-120 \mathrm{~cm} ; 7=$ calcite partially replacing feldspar phenocryst, Sample 418A-71-1, $109-113 \mathrm{~cm}(\# 5 \mathrm{D}) ; 8=$ calcite

$9=$ calcite replacing olivine phenocryst, Sample $418 \mathrm{~A}-71-1,109-113 \mathrm{~cm}(\# 5 \mathrm{D})$.

some plagioclase phenocrysts are also replaced by calcite. Alteration of the groundmass to patches of calcite rimmed with smectites also is observed. Calcite also fills veins and vesicles and, where it is associated with clay minerals in these sites, the calcite formed later. The veins often contain several secondary minerals with complex interrelations, making the sequence of formation very difficult to determine. The carbonates in the suite of samples studied are all calcite. The vein and vesicle calcites are generally quite pure, while those replacing phenocrysts or groundmass often contain small amounts of $\mathrm{FeO}^{*}$ and $\mathrm{MgO}$ (Table 5). This pervasive carbonation of the basaltic column at Hole $418 \mathrm{~A}$ is unrelated to the degree of weathering of the basalts, and appears to have occurred after the formation of the green and brown clay minerals.

\section{Zeolites}

Thin section and X-ray diffraction studies of the Hole 417A basalts down to 280 meters below the sea floor (i.e., Core 30 ) revealed no evidence for the presence of zeolites.

In contrast with this, trace amounts of zeolites were observed in samples from all depths in Hole 418A. In almost all cases, they occur in complex veins associated with calcite and clay minerals. However, occasionally they infill vesicles lined with brown smectites, e.g., Sample $418 \mathrm{~A}-36-5,80-87 \mathrm{~cm}$ (\#8A), or form patches in the weathered basalt of radiating crystals rimmed with iron hydroxides, e.g., Sample 418A-62-2, 129-134 cm (\#7). They range from white to pinkish red to gray, and usually form small radiating aggregates of needle-like crystals. All those in the suite of rocks studied are tentatively identified as phillipsite, but reliable microprobe analyses were not obtained.

\section{Silica}

$\mathrm{X}$-ray diffraction analysis of the breccia matrix in Samples 417A-26-3, 86-91 cm and 417A-28-2, 140-143 cm revealed the presence of silica, although this was not observed in any thin sections from the upper part of this hole.

Quartz, chalcedony, and opal occur in trace amounts throughout Hole $418 \mathrm{~A}$, most commonly in thick veins which are subsequently infilled with calcite. Association with smectite in veins is occasionally observed, e.g., Sample 418A-77-6, 44-50 cm (\#3B), and veinlets of quartz occur, particularly in the lower part of the hole. Sample 418A-60-1, 117-121 cm (\#2C) contains a lens of pinkish red silica adjacent to the weathered glassy margin of the 
basalt. Chemical analyses indicate that it contains about 1.6 per cent $\mathrm{CaO}, 0.2$ per cent $\mathrm{Al}_{2} \mathrm{O}_{3}, 0.8$ per cent $\mathrm{FeO}^{*}$, and 3.5 per cent $\mathrm{H}_{2} \mathrm{O}$; it probably represents a fragment of interflow sediment.

\section{Opaques}

The dominant secondary opaque mineral in the upper part of Hole 417A is hematite. It is very fine grained and occurs throughout the interval studied. It is disseminated throughout the groundmass of the weathered basaltic fragments and replaces opaque minerals and glass. Hematite often intermittently lines veins which are subsequently infilled first with a zone of green clay and then with calcite, e.g., Sample $417 \mathrm{~A}-26-1,40-46 \mathrm{~cm}$. In the breccia matrix, numerous tiny hematite veinlets are observed. There is a notable lack of sulfides in these samples. No sulfides were identified either in the weathered basaltic fragments or in the crosscutting veins and matrix of the breccias. The abundance of hematite and the lack of sulfides indicate that oxidizing conditions were prevalent during the weathering of this section of Hole 417A, and oxidation appears to have been one of the major alteration processes.

One of the most interesting aspects of the secondary opaque mineralogy is the occurrence of native copper in Sample 417A-26-3, 86-91 cm. The copper was hand-picked from the breccia matrix and its identity was confirmed by $\mathrm{X}$-ray diffraction. Native copper was also identified by the shipboard party in a sample from Section 417A-24-1, and has previously been observed in weathered basalts from Leg 37 (Andrews et al., 1977). The location of the native copper within the breccia matrix in association with clay minerals lends support to the hypothesis that it is a product of weathering rather than a residual phase in the original basalt. Possible mechanisms of formation are either reduction of copper in solution by reaction with iron minerals, as has been suggested for copper found in veins following fracture zones in basic volcanic flows and conglomerates in the Lake Superior region (Butler and Burbank, 1929), or by adsorption of metals onto colloidal material from undersaturated solutions (Andrews et al., 1977).

In contrast with Hole $417 \mathrm{~A}$, the dominant opaque weathering product throughout Hole $418 \mathrm{~A}$ is pyrite, with oxidation being confined to small sections of the sequence, or locally associated with cracks and brecciated zones. Most of the sulfide appears to be secondary, and no igneous globules of the type described by Czamanske and Moore (1977) were observed. Inclusion-filled sulfide blebs are often associated with calcite or yellow-brown smectites as pseudomorphs after olivine phenocrysts. Euhedral and anhedral grains are scattered throughout the groundmass, and glass is sometimes replaced by pyrite porphyroblasts. Rarely, networks of pure pyrite replacing plagioclase phenocrysts are observed, e.g., 418A-85-6, 29-32 cm (\#3C). The walls of many vesicles are lined with framboids of sulfides, e.g., $418 \mathrm{~A}-16-5,42-46 \mathrm{~cm}$ (\#1E); the vesicles are subsequently infilled with calcite or with green clay minerals. Along calcite veins, pyrite is in the form of irregular, inclusion-filled globules, although small, pure pyrite veinlets also occur in some samples. Sample 418A-15-1, $34 \mathrm{~cm}$ (\#1A) has an encrustation of pyrite on its outer surface.
Examples of the compositions of the sulfides are reported in Table 6. All the vein sulfides and any relatively large replacement patches are extremely pure $\mathrm{FeS}_{2}$. Nickel occurs in pyrites in both altered olivine and weathered groundmass sites, particularly in the smaller pyrite grains. The highest concentration of $\mathrm{Ni}$ recorded in these grains is 3.5 weight per cent, but there is no correlation between the nickel content of the pyrite and the site of the sulfide porphyroblast.

Chalcopyrite occurs in trace amounts at the bottom of Hole 418A. It is extremely fine grained and often contains inclusions, making it difficult to analyze. It replaces the groundmass and also occurs in pseudomorphs after olivine phenocrysts (Table 6, Analyses 12 and 13).

The vertical distribution of the sulfides indicates that they are more abundant in the lower part of the hole (downwards from about $730 \mathrm{~m}$ ) where they constitute up to 2 per cent of the rock. There are also two zones of oxidation seen in this suite of samples. The first occurs from about 415 to 485 meters sub-bottom (Cores 30 to 38 ), in which no sulfide is observed. The second interval is from about 667 to 725 meters sub-bottom (Cores 60 to 66); in this interval, sulfides are present only in trace amounts. In these oxidized zones, iron hydroxides commonly replace large areas of groundmass, and also infill veins, some of which are lined with green smectites and/or calcite. Smaller veins of iron hydroxides are also occasionally observed in other cored intervals (see Plate 3, Figure 6). In hand specimen, these hydroxides are yellowish brown and resemble limonite. In thin section, they vary from clear red and translucent to dark red and near opaque. Only the clear red areas will polish, and a typical analysis is shown in Table 7. The $\mathrm{SiO}_{2}$ content of about 7 per cent, which was obtained for all analyses of samples, can best be explained by the co-precipitation of colloidal silica with the iron hydroxide (Deer et al., 1962). A possible mechanism for the formation of the limonite is by slow percolation of the cold sea water through veinlets containing sulfides.

The presence of abundant sulfides in Hole 418A indicates that, in contrast with Hole $417 \mathrm{~A}$, weathering conditions were reducing. However, the zones of oxidation and the local, more recent oxidation along cracks and in breccia zones suggests that a later stage of weathering occurred under oxidizing conditions. This late-stage process affected only those areas of rock which still permitted penetration of a fluid, while those that had been sealed by precipitation of secondary minerals in the veins and vesicles retained their reducing mineralogy.

\section{Potassium Feldspar}

Most of the plagioclase phenocrysts in the upper part of Hole $417 \mathrm{~A}$ are replaced by $\mathrm{K}$-feldspar. A selection of microprobe analyses is presented in Table 8 , which indicates that the secondary feldspar is orthoclase. This replacement reaction must result in extensive leaching of calcium from the basalt with a concomitant uptake of potassium.

In contrast with this, the presence of K-feldspar is not as common in the weathered basalts from Hole $418 \mathrm{~A}$. Its main occurrence, although only in trace amounts, is in the zone of oxidation indicated by the opaque mineralogy, i.e., 415 to 
TABLE 6

Microprobe Analyses of Sulfides From Hole 418A

\begin{tabular}{|c|c|c|c|c|c|c|c|c|c|c|c|c|c|}
\hline $\begin{array}{c}\text { Element } \\
\text { (wt. \%) }\end{array}$ & 1 & 2 & 3 & 4 & 5 & 6 & 7 & 8 & 9 & 10 & 11 & 12 & 13 \\
\hline $\mathrm{Mg}$ & 0.17 & n.d. & n.d. & n.d. & n.d. & n.d. & 0.17 & n.d. & n.d. & n.d. & n.d. & n.d. & n.d. \\
\hline $\mathrm{Si}$ & 0.33 & 0.11 & 0.38 & 0.18 & 0.43 & n.d. & 0.18 & n.d. & n.d. & n.d. & n.d. & 0.45 & 0.23 \\
\hline $\mathrm{S}$ & 52.55 & 52.73 & 51.77 & 52.93 & 53.01 & 53.09 & 52.89 & 52.78 & 52.12 & 52.82 & 53.35 & 33.64 & 34.76 \\
\hline $\mathrm{Fe}$ & 46.93 & 46.69 & 44.95 & 46.28 & 46.97 & 43.02 & 47.20 & 46.96 & 47.33 & 47.23 & 46.83 & 30.09 & 30.14 \\
\hline $\mathrm{Ni}$ & n.d. & n.d. & 1.56 & 0.22 & n.d. & 3.43 & 0.34 & n.d. & n.d. & n.d. & n.d. & 1.28 & 0.47 \\
\hline $\mathrm{Cu}$ & n.d. & n.d. & n.d. & n.d. & n.d. & n.d. & n.d. & n.d. & n.d. & n.d. & n.d. & 32.67 & 34.20 \\
\hline Total & 99.98 & 99.53 & 98.66 & 99.61 & 100.41 & 99.54 & 100.78 & 99.74 & 99.45 & 100.05 & 100.18 & 98.13 & 99.80 \\
\hline \multirow[t]{5}{*}{$\mathrm{S}:(\mathrm{Fe}+\mathrm{Ni})$} & 1.95 & 1.97 & 1.94 & 1.98 & 1.97 & 2.00 & 1.95 & 1.95 & 1.92 & 1.95 & 1.98 & \multicolumn{2}{|c|}{$\begin{array}{c}\text { Atoms on } \\
\text { basis of } S=2\end{array}$} \\
\hline & & & & & & & & & & & $\mathrm{Si}$ & 0.03 & 0.02 \\
\hline & & & & & & & & & & & $\mathrm{Fe}$ & 1.03 & 1.00 \\
\hline & & & & & & & & & & & $\mathrm{Ni}$ & 0.05 & 0.02 \\
\hline & & & & & & & & & & & $\mathrm{Cu}$ & 0.98 & 1.00 \\
\hline
\end{tabular}

Note: Other elements sought include $\mathrm{Al}, \mathrm{Ti}, \mathrm{V}, \mathrm{Cr}, \mathrm{Mn}, \mathrm{Co}$, and $\mathrm{Zn}$; n.d. = not detected. 1 = irregular inclusion-filled "globules" along a carbonate vein, Sample 418A-19-5, 42-46 cm (\#1E); 2 = network of linked blebs in altered groundmass, Sample 418A-52-4, 75$80 \mathrm{~cm}$ (\#6A); 3 = small blebs in altered groundmass, Sample 418A-52-4, 75-80 cm (\#6A); 4 = small grains within pseudomorphs after olivine phenocrysts, Sample 418A-71-3, 101-104 cm (\#7); 5 = sulfide encrusting parts of walls of vein filled with carbonate, and locally filling vein with sulfide networks, Sample 418A-72-3,130-134 cm (\#5); 6 = small sulfide grain within altered groundmass, Sample 418A-72-3, 130-134 cm (\#5); 7 = large grain appears to replace olivine and plagioclase, Sample 418A-76-2, 83-88 $\mathrm{cm}$ (\#1I); 8 = grains along a thin sulfide vein, Sample 418A-79-3, 42-118 cm (\#1I); $9=$ blebs of sulfide in altered areas within the basaltic groundmass, Sample 418A-79-3, 42-118 cm (\#1I); $10=$ grains and blebs replacing silicates within doleritic groundmass, Sample 418A-79-3, 42-118 cm (\#1I); 11 = sulfide network replacing plagioclase, Sample 418A-85-6, 29-32 cm (\#3C); 12 = irregular patches of chalcopyrite replacing fine-grained groundmass, Sample 418A-85-6, 29-32 cm $(\# 3 C) ; 13=$ irregular inclusion-filled sulfide patch replacing margin of a pseudomorph after olivine phenocryst, Sample 418A-86-4, 48-124 cm (\#7A).

TABLE 7

Microprobe Analysis of Limonite in Sample 418A-62-2, 129-134 cm (\#7)

\begin{tabular}{lr}
\hline Oxide & wt. \% \\
\hline $\mathrm{SiO}_{2}$ & 7.26 \\
$\mathrm{Al}_{2} \mathrm{O}_{3}$ & 1.08 \\
$\mathrm{FeO}^{*}$ & 79.37 \\
$\mathrm{MgO}$ & 0.36 \\
Total & 88.07 \\
\hline
\end{tabular}

Note: Other elements sought include

$\mathrm{Ti}, \mathrm{V}, \mathrm{Cr}, \mathrm{Mn}$, and $\mathrm{Ni}$.

485 meters sub-bottom. In many instances, the K-feldspar replaces only the cores of zoned plagioclase phenocrysts.

\section{CHEMICAL CHANGES DURING WEATHERING}

The changes observed in the mineralogy of the basalts during weathering should be reflected in the chemistry of the altered samples. Low-temperature weathering reactions of basalt and sea water have previously been shown to result in significant uptake of $\mathrm{K}, \mathrm{Rb}, \mathrm{P}$, and $\mathrm{H}_{2} \mathrm{O}$ with a concomitant loss of $\mathrm{Ca}$ and $\mathrm{Mg}$ (e.g., Thompson, 1973; Robinson et al., 1977).

Major and selected trace element analyses were conducted on six samples from Hole 417A (all breccias being omitted), and a suite of 22 samples from Hole 418A. Samples 417A-30-3, 104-110 cm; 418A-36-2, 25-37 cm (\#2); and 418A-38-1, 42-47 cm (\#2C) displayed weathered rims and slightly fresher interiors. This allowed separation of the two zones for analysis and provided a comparison of the chemistry of the weathered rim with that of its precursor.
TABLE 8

\begin{tabular}{|c|c|c|c|c|}
\hline $\begin{array}{c}\text { Oxide } \\
\text { (wt. \%) }\end{array}$ & 1 & 2 & 3 & 4 \\
\hline $\mathrm{SiO}_{2}$ & 63.92 & 64.31 & 64.82 & 64.42 \\
\hline $\mathrm{Al}_{2} \mathrm{O}_{3}$ & 17.89 & 17.84 & 18.34 & 18.30 \\
\hline $\mathrm{CaO}$ & 0.10 & 0.10 & n.d. & n.d. \\
\hline $\mathrm{K}_{2} \mathrm{O}$ & 16.58 & 16.07 & 16.06 & 16.35 \\
\hline $\mathrm{FeO}^{*}$ & 0.72 & 1.19 & 0.25 & 0.22 \\
\hline \multirow[t]{2}{*}{ Total } & 99.21 & 99.51 & 99.47 & 99.29 \\
\hline & \multicolumn{4}{|c|}{ Cations per 32 oxygens } \\
\hline $\mathrm{Si}$ & 11.98 & 11.99 & 12.02 & 11.99 \\
\hline $\mathrm{Al}$ & 3.95 & 3.92 & 4.01 & 4.02 \\
\hline $\mathrm{Ca}$ & 0.02 & 0.02 & - & - \\
\hline $\mathrm{K}$ & 3.96 & 3.82 & 3.80 & 3.88 \\
\hline $\mathrm{Fe}$ & 0.11 & 0.19 & 0.04 & 0.03 \\
\hline Total & 20.02 & 19.94 & 19.87 & 19.92 \\
\hline
\end{tabular}

Note: $\mathrm{FeO}^{*}=$ total iron as $\mathrm{FeO}$; n.d. $=$ not detected; $\mathrm{Na}_{2} \mathrm{O}$ and $\mathrm{MgO}$ were not detected. Analyses are averages for individual altered feldspar phenocrysts from Sample 417A-23-1, 118-120 cm (Analyses 1, 2, and 3) and Sample 417A-26-5, $41-45 \mathrm{~cm}$ (Analysis 4).

The results of the bulk chemical analyses are presented in Table 9.

Silica concentrations in the weathered rocks are quite variable but generally do not differ greatly from values in the fresh rocks of 48 to 50 per cent $\mathrm{SiO}_{2}$. Some samples 
TABLE 9

Major and Selected Trace Element Analyses of Weathered Basalts From Holes 417A and 418A

\begin{tabular}{|c|c|c|c|c|c|c|c|c|c|c|c|c|c|c|}
\hline \multirow[b]{2}{*}{$\begin{array}{l}\text { Oxide } \\
\text { (wt. \%) }\end{array}$} & \multicolumn{6}{|c|}{ Hole $417 \mathrm{~A}$} & \multicolumn{8}{|c|}{ Hole $418 \mathrm{~A}$} \\
\hline & $\begin{array}{c}23-1 \\
118-120 \mathrm{~cm}\end{array}$ & $\begin{array}{c}26-1 \\
40-46 \mathrm{~cm}\end{array}$ & $\begin{array}{c}26-5 \\
41-45 \mathrm{~cm}\end{array}$ & $\begin{array}{c}29-3, \\
136-138 \mathrm{~cm}\end{array}$ & $\begin{array}{l}30-3,104 \\
\mathrm{Rim}\end{array}$ & $\begin{array}{l}4.110 \mathrm{~cm} \\
\text { Interior }\end{array}$ & $\begin{array}{l}16-2 \cdot 1 \mathrm{~A} \\
31-36 \mathrm{~cm}\end{array}$ & $\begin{array}{l}17-3-1 \mathrm{~A} \\
2-6 \mathrm{~cm}\end{array}$ & $\begin{array}{c}21-1-7 B \\
107-112 \mathrm{~cm}\end{array}$ & $\begin{array}{l}25-3-1 \mathrm{~B}, \\
24-28 \mathrm{~cm}\end{array}$ & $\begin{array}{c}26-3-5 \\
104-108 \mathrm{~cm}\end{array}$ & $\begin{array}{l}30-3 \cdot 1 \mathrm{C} \\
35-38 \mathrm{~cm}\end{array}$ & $\begin{array}{l}34-1-2 \mathrm{G} \\
111-118 \mathrm{~cm}\end{array}$ & $\begin{array}{c}34-5-6 \mathrm{C} \\
102-109 \mathrm{~cm}\end{array}$ \\
\hline $\mathrm{SiO}_{2}$ & 48.89 & 47.10 & 48.01 & 46.34 & 47.82 & 47.28 & 47.16 & 48.84 & 47.95 & 49.80 & 48.12 & 47.81 & 47.98 & 45.96 \\
\hline $\mathrm{Al}_{2} \mathrm{O}_{3}$ & 19.88 & 18.14 & 17.06 & 17.87 & 17.48 & 17.47 & 17.03 & 17.89 & 16.51 & 15.60 & 18.46 & 16.02 & 17.87 & 16.78 \\
\hline $\mathrm{Fe}_{2} \mathrm{O}_{3}$ & 10.57 & 6.95 & 8.82 & 5.34 & 7.41 & 6.45 & 3.61 & 3.64 & 3.65 & 3.21 & 5.27 & 3.54 & 3.39 & 7.17 \\
\hline $\mathrm{FeO}^{\mathrm{b}}$ & 0.45 & 2.09 & 1.59 & 3.28 & 3.43 & 3.77 & 3.97 & 4.11 & 5.23 & 5.66 & 3.81 & 5.74 & 4.87 & 3.03 \\
\hline $\mathrm{MgO}$ & 1.82 & 5.15 & 4.78 & 5.66 & 4.75 & 5,43 & 6.77 & 7.50 & 6.72 & 7.43 & 7.73 & 6.94 & 6.61 & 6.96 \\
\hline $\mathrm{CaO}$ & 4.98 & 8.30 & 6.48 & 12.70 & 9.08 & 11.46 & 13.39 & 11.43 & 12.99 & 12.53 & 6.92 & 12.87 & 12.85 & 11.47 \\
\hline $\mathrm{Na}_{2} \mathrm{O}$ & 2.63 & 2.12 & 1.78 & 2.23 & 2.48 & 2.35 & 2.66 & 2.94 & 2.59 & 2.69 & 2.79 & 2.45 & 2.37 & 2.56 \\
\hline $\mathrm{K}_{2} \mathrm{O}$ & 3.56 & 3.30 & 4.87 & 1.01 & 1.87 & 1.04 & 0.67 & 0.18 & 0.17 & 0.06 & 1.02 & 0.24 & 0.20 & 0.94 \\
\hline $\mathrm{TiO}_{2}$ & 1.69 & 1.55 & 1.44 & 1.30 & 1.51 & 1.41 & 1.10 & 1.21 & 1.13 & 1.24 & 1.27 & 1.23 & 1.14 & 1.14 \\
\hline $\mathrm{P}_{2} \mathrm{O}_{5}$ & 0.46 & 0.27 & 0.21 & 0.15 & 0.22 & 0.18 & 0.12 & 0.13 & 0.14 & 0.15 & 0.09 & 0.13 & 0.13 & 0.13 \\
\hline $\mathrm{MnO}$ & 0.30 & 0.17 & 0.11 & 0.14 & 0.12 & 0.15 & 0.14 & 0.11 & 0,16 & 0.15 & 0.10 & 0.19 & 0.15 & 0.16 \\
\hline $\mathrm{H}_{2} \mathrm{O}^{+\mathrm{c}}$ & 5.10 & 4.10 & 4.33 & 2.61 & 3.32 & 2.33 & 1.73 & 1.94 & 1.65 & 1.62 & 4.75 & 1.27 & 1.25 & 2.95 \\
\hline $\mathrm{CO}_{2}{ }^{\mathrm{c}}$ & 0.44 & 1.34 & 1.26 & 2.33 & 0.41 & 1.30 & 2.81 & 0.97 & 1.13 & 0.63 & 0.12 & 1.00 & 0.73 & 2.25 \\
\hline $\begin{array}{l}\text { Total } \\
\text { (ppm) }\end{array}$ & 100.77 & 100.58 & 100.74 & 100.96 & 99.90 & 100.62 & 101.16 & 100.89 & 100.02 & 100.77 & 100.45 & 99.43 & 99.54 & 100.50 \\
\hline $\mathrm{Rb}$ & 57 & 29 & so & 13 & 21 & 13 & 5 & 1 & 2 & 0 & 11 & 4 & 2 & 14 \\
\hline $\mathrm{Sr}$ & 102 & 114 & 125 & 100 & 116 & 101 & 113 & 114 & 107 & 102 & 116 & 99 & 103 & 110 \\
\hline $\mathrm{Y}$ & 53 & 36 & 32 & 28 & 36 & 28 & 22 & 25 & 24 & 22 & 23 & 23 & 24 & 26 \\
\hline $\mathrm{Zt}_{\mathrm{t}}$ & 100 & 91 & 84 & 77 & 92 & 84 & 58 & 66 & 58 & 66 & 68 & 66 & 59 & 65 \\
\hline $\mathrm{Nb}$ & 4 & 2 & 2 & 2 & 4 & 4 & 4 & 1 & 2 & 2 & 2 & 2 & 4 & 2 \\
\hline
\end{tabular}

Major and trace element analyses by X-ray fluorescence.

${ }^{{ }^{c}} \mathrm{H}_{2} \mathrm{O}^{+}$and $\mathrm{CO}_{2}$ determined using a Hewlett-Packard $\mathrm{CHN}$ analyzer.

TABLE 9 - Continued

\begin{tabular}{|c|c|c|c|c|c|c|c|c|c|c|c|c|c|c|}
\hline & & & & & & & & ole $418 \mathrm{~A}$ & & & & & & \\
\hline $\begin{array}{l}\text { Oxide } \\
\text { (wt. "s) }\end{array}$ & $\begin{array}{l}\text { 36-2-2, } \\
\operatorname{Rim}\end{array}$ & $\begin{array}{l}25 \cdot 37 \mathrm{~cm} \\
\text { Interior }\end{array}$ & $\begin{array}{l}38-1-2 C \\
\operatorname{Rim}\end{array}$ & $\begin{array}{l}42-47 \mathrm{~cm} \\
\text { Interior }\end{array}$ & $\begin{array}{l}40-1-4 \mathrm{~B} \\
71-76 \mathrm{~cm}\end{array}$ & $\begin{array}{c}57-3-3 \Lambda \\
100-105 \mathrm{~cm}\end{array}$ & $\begin{array}{l}60-5-1 \mathrm{~J} \\
89-94 \mathrm{~cm}\end{array}$ & $\begin{array}{c}62-2-7 \\
129-134 \mathrm{~cm}\end{array}$ & $\begin{array}{c}63-2-5 \\
134-138 \mathrm{~cm}\end{array}$ & $\begin{array}{l}65.3-4 \mathrm{C} \\
53-57 \mathrm{~cm}\end{array}$ & $\begin{array}{l}67-2-3 \mathrm{~F} \\
119-124 \mathrm{~cm}\end{array}$ & $\begin{array}{l}73-6-3 \mathrm{~A}, \\
99-103 \mathrm{~cm}\end{array}$ & $\begin{array}{c}76-2-11 \\
83-88 \mathrm{~cm}\end{array}$ & $\begin{array}{c}83-1-1 \mathrm{~J} \\
100-104 \mathrm{~cm}\end{array}$ \\
\hline $\mathrm{SiO}_{2}$ & 48.60 & 47.91 & 47.38 & 48.51 & 47.64 & 48.99 & 47.25 & 49.68 & 49.21 & 48.29 & 48.61 & 48.20 & 48.45 & 48.18 \\
\hline $\mathrm{Al}_{2} \mathrm{O}_{3}$ & 18.54 & 17.89 & 17.48 & 18.91 & 16.98 & 17.12 & 16.12 & 15.81 & 17.74 & 16.53 & 16.75 & 16.23 & 16.29 & 16.55 \\
\hline $\mathrm{Fe}_{2} \mathrm{O}_{3}$ & 8.13 & 6.81 & 9.66 & 6.14 & 6.56 & 2.79 & 8.42 & 7.24 & 5.45 & 6.23 & 3.51 & 4.19 & 4.63 & 3.03 \\
\hline $1 \mathrm{co}^{\mathrm{b}}$ & 2.02 & 2.81 & 1.95 & 2.51 & 3.68 & 6.87 & 4,40 & 3.61 & 4.65 & 3.70 & 5.66 & 5.05 & 5.18 & 5.92 \\
\hline $\mathrm{MgO}$ & 6.40 & 5.88 & 7.29 & 6.21 & 5.34 & 6.09 & 6.38 & 6.11 & 6.07 & 6.59 & 6.38 & 7.01 & 7.56 & 7.15 \\
\hline $\mathrm{CaO}$ & 7.40 & 10.70 & 5.73 & 8.67 & 10.34 & 12,43 & 10.86 & 9.96 & 11.30 & 11.85 & 12.41 & 11.87 & 11.52 & 13.94 \\
\hline $\mathrm{Na}_{2} \mathrm{O}$ & 2.75 & 2.46 & 2.67 & 2.59 & 2.26 & 2.47 & 2.64 & 2.81 & 2.68 & 2.63 & 2.31 & 2.29 & 2.49 & 2.25 \\
\hline $\mathrm{K}_{2} \mathrm{O}$ & 1.96 & 1.85 & 2.19 & 1.58 & 2.65 & 0.16 & 0.49 & 0.76 & 0.52 & 0.52 & 0.12 & 0.11 & 0.09 & 0.07 \\
\hline $\mathrm{TiO}_{2}$ & 1.25 & 1.20 & 1.19 & $\begin{array}{l}1.29 \\
\end{array}$ & 1.15 & 1.42 & 1.49 & 1.55 & 1.32 & 1.24 & 1.17 & 1.24 & 1.30 & 1.10 \\
\hline $\mathrm{P}_{2} \mathrm{O}_{5}$ & 0.13 & 0.19 & 0.13 & 0.14 & 0.16 & 0.14 & 0.18 & 0.22 & 0.14 & 0.13 & 0.14 & 0.15 & 0.13 & 0.11 \\
\hline $\mathrm{MnO}$ & 0.08 & 0.11 & 0.06 & 0.08 & 0.12 & 0.15 & 0.14 & 0.13 & 0.14 & 0.11 & 0.13 & 0.12 & 0.15 & 0.17 \\
\hline $\mathrm{H}_{2} \mathrm{O}^{+\mathrm{c}}$ & 2.74 & 0.99 & 5.43 & 4.21 & 3.06 & 1.57 & 1.65 & 2.46 & 1.58 & 1.47 & 1.87 & 3.08 & 1.89 & 0.30 \\
\hline $\mathrm{CO}_{2}^{\mathrm{c}}$ & 0.24 & 0.21 & 0.20 & 0.12 & 1.03 & 0.23 & 0.92 & 0.82 & 0.34 & 1.37 & 0.97 & 1.45 & 1.01 & 1.55 \\
\hline $\begin{array}{l}\text { Total } \\
\text { (ppm) }\end{array}$ & 100.24 & 99.01 & 101.28 & 100.96 & 100.97 & 100.43 & 100.94 & 101.14 & 101.14 & 100.66 & 100.03 & 100.99 & 100.69 & 100.32 \\
\hline $\mathrm{Rb}$ & 18 & 19 & 26 & 16 & 26 & 1 & 10 & 18 & 14 & 11 & 0 & 1 & 0 & 1 \\
\hline Sr & 118 & 105 & 107 & 111 & 330 & 98 & 106 & 112 & 105 & 110 & 103 & 114 & 112 & 106 \\
\hline $\mathrm{Y}$ & 33 & 32 & 34 & 25 & 30 & 29 & 31 & 37 & 29 & 30 & 27 & 24 & 24 & 22 \\
\hline $\mathrm{Zr}$ & 65 & 63 & 65 & 69 & 49 & 73 & 81 & 87 & 71 & 60 & 65 & 66 & 73 & 60 \\
\hline $\mathrm{Nb}$ & 4 & 2 & 4 & 1 & 4 & 2 & 4 & 6 & 2 & 2 & 2 & 2 & 2 & 4 \\
\hline
\end{tabular}

a Major and trace element analyses by X-ray fluorescence.

${ }^{6}$ Ferrous iron determined by me thod of Whipple (1974).

${ }^{\mathrm{C}_{2}} \mathrm{H}_{2} \mathrm{O}^{+}$and $\mathrm{CO}_{2}$ determined using a Hewlett-Packard $\mathrm{CHN}$ analyzer.

which now contain abundant calcite, e.g., 418A-34-5, 102-109 cm (\#6C), show a slight decrease in $\mathrm{SiO}_{2}$ content; those in which the weathering reactions have involved the precipitation of quartz or chalcedony show very little variation, e.g., 418A-73-6, 99-103 cm (\#3A). There is no correlation with the degree of weathering, as depicted by the increase in $\mathrm{H}_{2} \mathrm{O}^{+}$content, for either Hole $417 \mathrm{~A}$ or $418 \mathrm{~A}$.

Calcium generally decreases in the weathered basalts and shows a good correlation with $\mathrm{H}_{2} \mathrm{O}^{+}$content, i.e., $\mathrm{r}=-0.88$ (Figure 1). However, the expected correlation between the $\mathrm{CaO}$ and $\mathrm{CO}_{2}$ concentrations due to carbonate formation is not observed. The final amount of calcium observed in the weathered basalt is determined by the relative importance of the following three processes: (1) removal of calcium from the rock through replacement of plagioclase by K-feldspar or smectites; (2) addition of calcium to the rock by the precipitation of calcite in vesicles, veinlets, replacing olivine, etc.; and (3) retention of calcium originally in the rock by the replacement of feldspars with calcite. In these samples, the integrated effect of these processes has been a loss of calcium from the rocks. This indicates that leaching of calcium during breakdown of plagioclase has been the overriding factor governing the observed calcium concentrations in the weathered basalts.

The magnesium concentrations in the samples from Hole $418 \mathrm{~A}$ show only minor variations with increasing weath- 


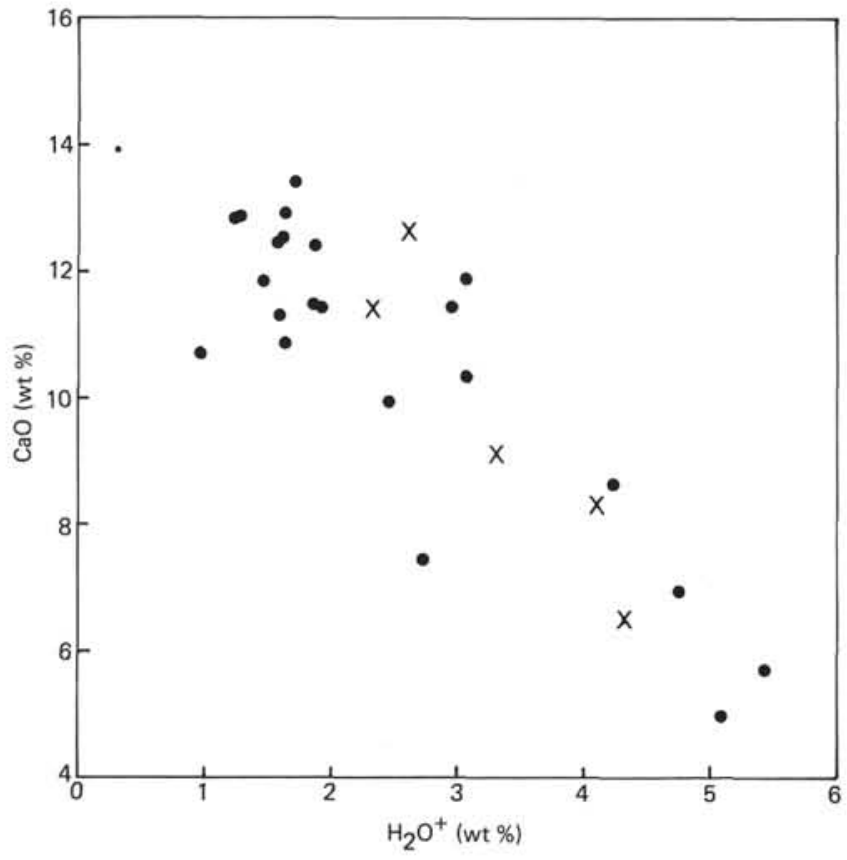

Figure 1. $\mathrm{CaO}$ versus $\mathrm{H}_{2} \mathrm{O}^{+}$contents for Holes $417 \mathrm{~A}$ and $418 \mathrm{~A}$ weathered basalts. Symbols for Figures 1 through 6 are as follows: $x=$ basalts from Hole $417 A, \bullet=$ basalts from Hole $418 \mathrm{~A}$.

ering. This is in contrast with the samples from Hole $417 \mathrm{~A}$, in which the shipboard analyses of the freshest samples gave an average $\mathrm{MgO}$ content of $5.96 \pm 0.75$ per cent. In the samples analyzed here, there is a decrease in the $\mathrm{MgO}$ content with increasing $\mathrm{H}_{2} \mathrm{O}^{+}$content (Figure 2). This difference in chemistry between the two holes can be explained by the variations in the secondary minerals. The brown smectites that pseudomorph olivine in Hole 418A have $\mathrm{MgO}$ contents of 14 to 20 per cent (Table 2, Analysis 12), and so retain much of the magnesium originally present in the olivine. The basalts of Hole 417A are more highly weathered and oxidized, and the celadonite replacing olivine phenocrysts contains only about 4 per cent $\mathrm{MgO}$ (Table 2, Analysis 4); hence, much of the $\mathrm{MgO}$ originally present is leached from the basalt.

The total iron concentrations generally range between 8 and 11 per cent $\mathrm{Fe}_{2} \mathrm{O}_{3}$ (Figure 3 ). Thin-section observations indicate that the higher $\mathrm{Fe}_{2} \mathrm{O}_{3}$ values determined in three of the samples from Hole $418 \mathrm{~A}$ are due to the presence of veinlets and patches within the groundmass of the red limonite previously discussed. The high values of total iron observed in Hole 417A basalts are probably due to the introduction of iron into the basalt during the formation of the celadonite. The analyses of the zoned samples suggests that some of the basalts gain small amounts of iron, but there is no well-defined correlation with the extent of weathering. However, the $\mathrm{Fe}^{3+} / \mathrm{Fe}^{2+}+\mathrm{Fe}^{3+}$ ratio increases with water content (Figure 4), particularly in the Hole $417 \mathrm{~A}$ basalts. In these basalts, the increase reflects the oxidation mineralogy previously discussed, particularly the abundance of hematite and the absence of sulfides. In the samples from Hole 418A, there also appears to be a general increase in the $\mathrm{Fe}^{3+} / \mathrm{Fe}^{2+}+\mathrm{Fe}^{3+}$ ratio with increasing $\mathrm{H}_{2} \mathrm{O}^{+}$

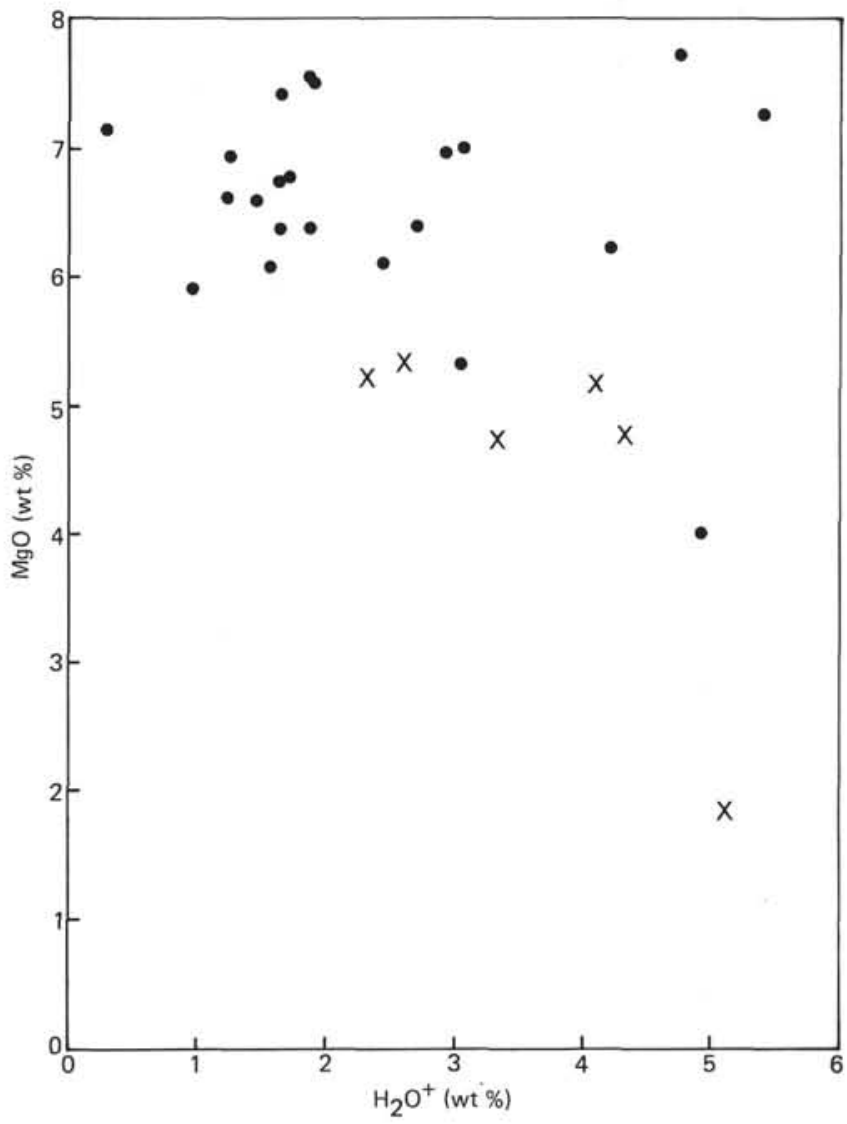

Figure 2. $\mathrm{MgO}$ versus $\mathrm{H}_{2} \mathrm{O}^{+}$contents in weathered basalts.

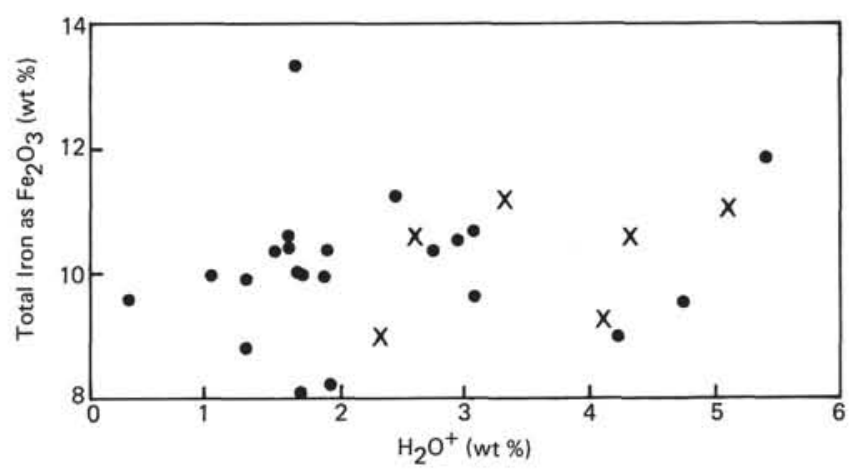

Figure 3. Variation of total iron, expressed as $\mathrm{Fe}_{2} \mathrm{O}_{3}$, with water content of basalts from Holes $417 \mathrm{~A}$ and $418 \mathrm{~A}$.

content, with the highest values being obtained for those samples containing limonite, and the lowest values for those samples with abundant pyrite.

The concentrations of $\mathrm{K}_{2} \mathrm{O}$ observed in the weathered basalt will depend mostly on the abundance of K-feldspar and celadonite. A general trend of $\mathrm{K}_{2} \mathrm{O}$ uptake with increasing $\mathrm{H}_{2} \mathrm{O}^{+}$content is observed; however, the variation between them can be attributed to their participation in different weathering reactions (Figure 5). Although they are both taken up during the formation of the celadonite, uptake of large quantities of water will occur during the formation of smectites, while potassium will be taken up during the replacement of plagioclase with $\mathrm{K}$-feldspar. 


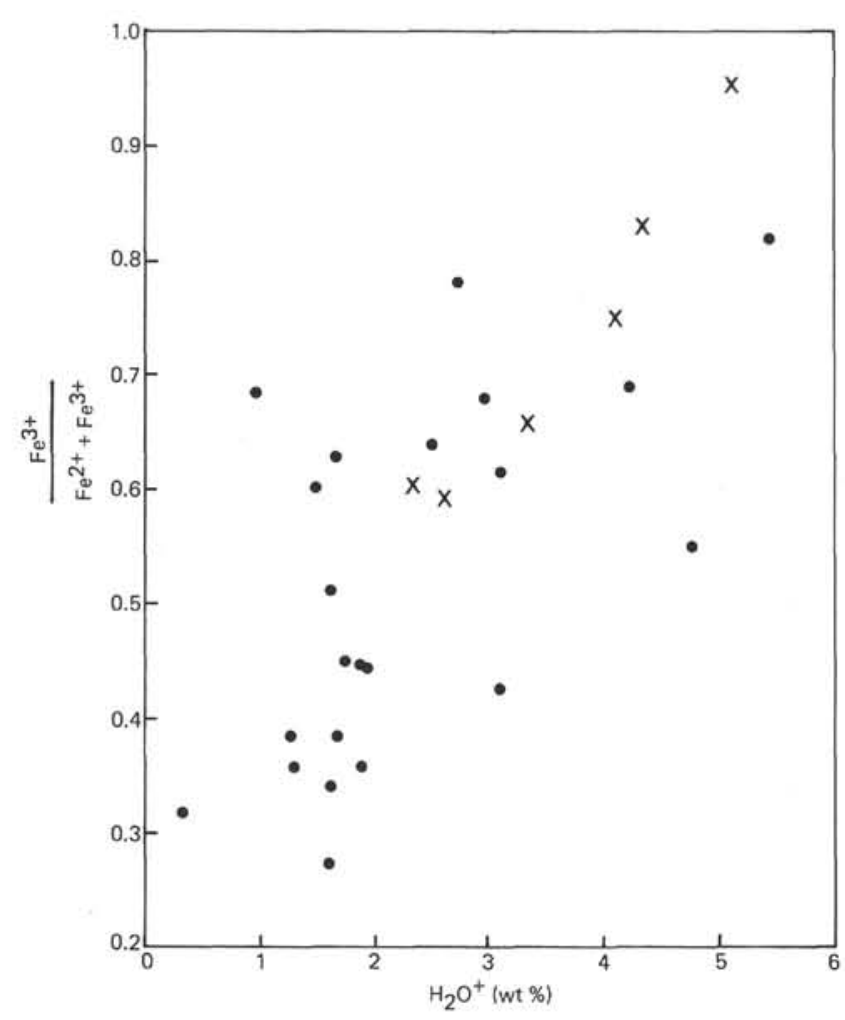

Figure 4. $\mathrm{Fe}^{3+} / \mathrm{Fe}^{2+}+\mathrm{Fe}^{3+}$ ratio versus $\mathrm{H}_{2} \mathrm{O}^{+}$content.

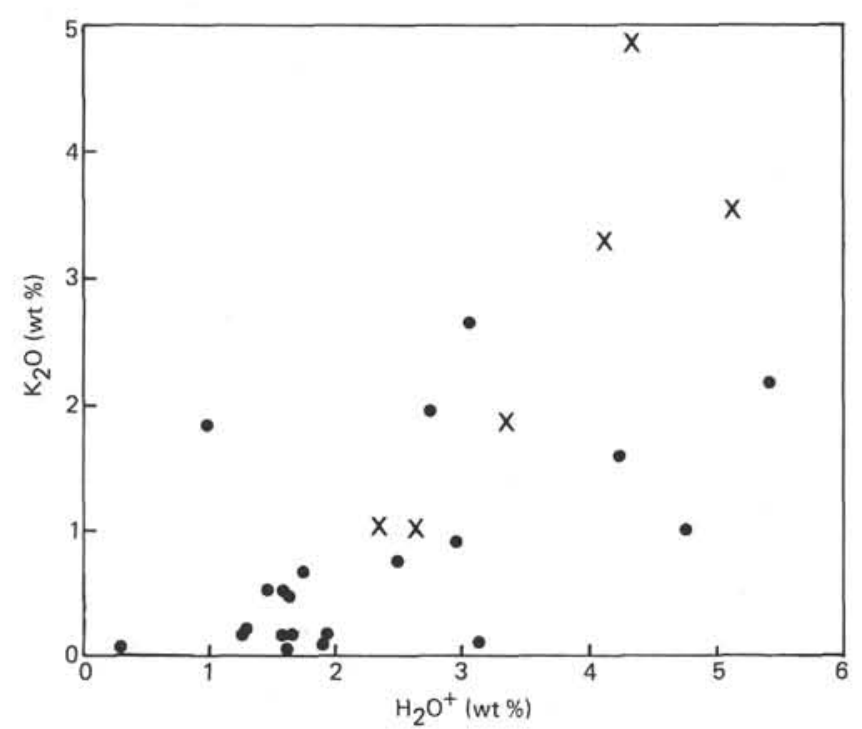

Figure 5. $\mathrm{K}_{2} \mathrm{O}$ versus $\mathrm{H}_{2} \mathrm{O}^{+}$concentrations in weathered basalts.

The concentrations of $\mathrm{K}_{2} \mathrm{O}$ in the samples from Hole $417 \mathrm{~A}$ are higher than are normally encountered in weathered ocean floor basalts. However, thin-section studies indicate that this is due to the well developed secondary mineralogy rather than to a completely different weathering process. These exceptionally high concentrations could have important implications for the geochemical mass balance of potassium. Although the frequency with which oceanic basalts take up such vast quantities of potassium is as yet unknown, it is possible to make some preliminary calculations to determine the significance of such a process as a sink for potassium in the oceans. Assuming an uptake of 5.0 weight per cent $\mathrm{K}_{2} \mathrm{O}$ and the density of basalt to be $2.9 \mathrm{~g} / \mathrm{cm}^{3}$, an uptake rate of $\mathrm{K}_{2} \mathrm{O}$ of $1.33 \times 10^{-9} \mathrm{~g} / \mathrm{cm}^{3} / \mathrm{yr}$ is indicated for this 109-m.y.-old crust. This is comparable with the rate calculated by Thompson (1973) for 16-m.y.old crust. However, it is likely that uptake of potassium has not been a continuous process, since the oceanic crust would become sealed to penetration of sea water at an earlier time by the formation of an overlying sedimentary layer. Hence, the uptake of $\mathrm{K}_{2} \mathrm{O}$ in these samples was probably much more rapid than this calculation indicates.

An alternative approach is to compare the uptake of potassium with its major input mechanism to the oceans. The annual river input of potassium to the oceans is $7.4 \times 10^{13} \mathrm{~g}$ (Garrels and Mackenzie, 1971). Assuming that the altered basalt takes up 5.0 weight per cent $\mathrm{K}_{2} \mathrm{O}$, then it is only necessary to weather $0.61 \mathrm{~km}^{3}$ of basalt to account for the annual river input of potassium. The surface area of basalt intruded annually is $2.75 \mathrm{~km}^{2}$, assuming the length of the ridge system is $5.5 \times 10^{4} \mathrm{~km}$ and the average spreading rate for all oceans is $5 \mathrm{~cm} / \mathrm{yr}$; if low temperature weathering penetrates down to $1 \mathrm{~km}$, then $0.61 \mathrm{~km}^{3}$ represents only 22 per cent of the annual volume of basalt that is potentially available for weathering. These calculations therefore indicate that weathering of basalts is a significant sink for $\mathrm{K}$ in the oceans, but the absolute fluxes cannot be determined until further information concerning the abundance of these $\mathrm{K}$-rich weathered basalts is available.

Rubidium is also taken up during low-temperature weathering, and its concentration increases concomitantly with that of $\mathrm{K}_{2} \mathrm{O}$ (Figure 6). The correlation between $\mathrm{Rb}$ and $\mathrm{K}_{2} \mathrm{O}$ contents $(\mathrm{r}=0.92)$ suggests that $\mathrm{Rb}$ concentrations are dominantly controlled by the same chemical processes as $\mathrm{K}_{2} \mathrm{O}$.

$\mathrm{Na}_{2} \mathrm{O}$ concentrations are quite uniform and do not show any major changes with increasing alteration. However, some samples from Hole 417A show quite low values of $\mathrm{Na}_{2} \mathrm{O}$ (e.g., 417A-26-5, 41-45 cm contains $1.78 \% \mathrm{Na}_{2} \mathrm{O}$ ) which may be indicative of loss of sodium; this is not observed in Hole 418A.

$\mathrm{TiO}_{2}, \mathrm{P}_{2} \mathrm{O}_{5}$, and $\mathrm{Al}_{2} \mathrm{O}_{3}$ concentrations appear to be little affected by low-temperature weathering. Although there is no evidence to suggest massive fluxes or introduction of these elements from sea water, this does not preclude the possibility of some mobilization of these elements and their uptake into secondary phases.

Manganese also generally shows very little variation in concentration in the weathered basalts. However, in Sample 417A-23-1, 118-120 cm, in which Mn-rich carbonate replaces some feldspar phenocrysts, the $\mathrm{MnO}$ concentration is higher $(0.3 \mathrm{wt} . \%)$ than in the other basalts from the same hole. This indicates that manganese can be mobilized during low-temperature weathering reactions, but usually this is insufficient to affect the whole-rock $\mathrm{MnO}$ concentrations.

\section{DOWNHOLE VARIATIONS IN HOLE 418A}

Figure 7 illustrates the downhole variations in chemistry and mineralogy in Hole 418A. Carbonation and smectite 


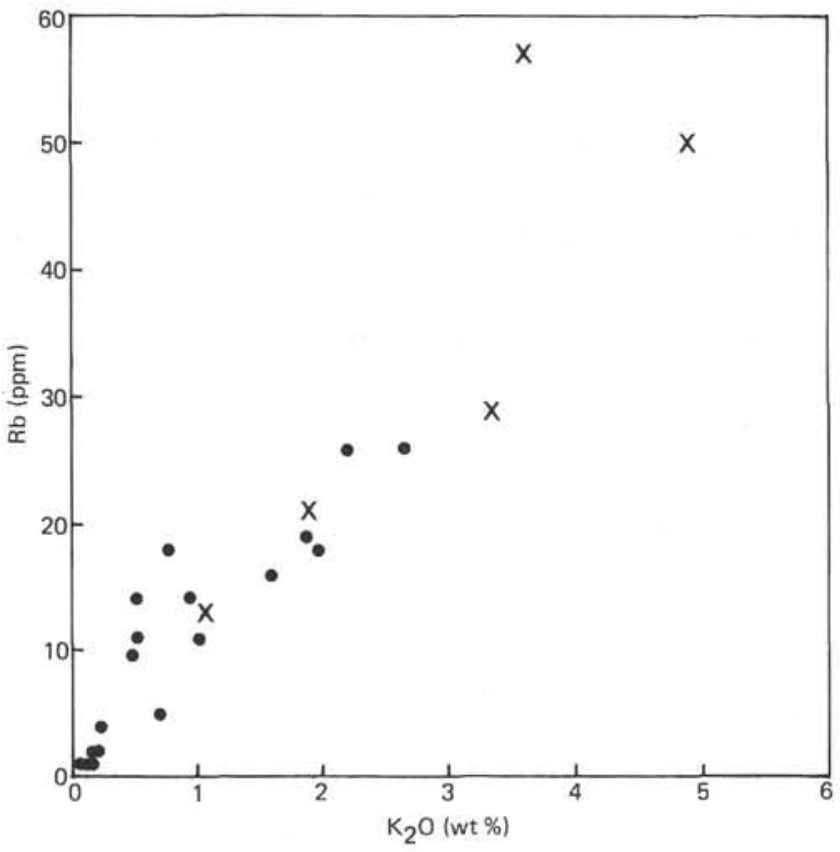

Figure 6. $\mathrm{K}_{2} \mathrm{O}$ (wt.\%) versus $\mathrm{Rb}$ (ppm) contents of weathered basalts.

formation are pervasive throughout the stratigraphic sequence. However, the degree of weathering is clearly not uniform throughout the hole. There is no correlation between the degree of weathering and the sub-basement depth, although the interval from about 725 meters to the bottom of the hole $(868 \mathrm{~m})$ appears to be less weathered, and shows little variation in the oxide contents. However, water contents are still generally $>1$ per cent, indicating some incipient weathering in all samples.

The oxidation zones that were defined on the basis of the opaque mineralogy are also reflected in the downhole chemical variations. The upper oxidation zones (from 415 to 485 m) has a high $\mathrm{Fe}^{3+} / \mathrm{Fe}^{2+}+\mathrm{Fe}^{3+}$ ratio, particularly in its lower portion where iron oxides and hydroxides are in greater abundance; a small overall increase in total iron is also observed. The lower oxidation zone (667 to $725 \mathrm{~m}$ ) again shows high values of both total iron content and the $\mathrm{Fe}^{3+1}$ $\mathrm{Fe}^{2+}+\mathrm{Fe}^{3+}$ ratio. It is interesting to note that some of the largest variations in chemistry, particularly the concentrations of $\mathrm{CaO}$ and $\mathrm{K}_{2} \mathrm{O}$ also coincide with these oxidation zones, presumably due to the appearance of K-feldspar in the upper zone.

The mineralogical and chemical variations suggest that the whole stratigraphic sequence was initially weathered at low temperatures under reducing conditions with the formation of smectites and pyrite, and with some small chemical changes. However, subsequent localized oxidation was responsible for the larger chemical variations observed in some sections.

\section{SEQUENCE OF WEATHERING}

The secondary mineralogy observed in the upper part of Hole 417A lacks any evidence of metamorphism, which indicates that temperatures were low during weathering of these basalts, probably not exceeding $50^{\circ} \mathrm{C}$. The presence of the holes inside the plagioclase phenocrysts, and the similarity in composition between the vesicle fillings and olivine pseudomorphs suggests that there may have been an early stage of leaching of these basalts. This was followed by oxidizing conditions, indicated by the presence of hematite and celadonite, during which time veins, vesicles, and the sites of former phenocrysts were filled with secondary minerals. These oxidizing conditions were prevalent during much of the weathering process, including the late-stage carbonation. However, the presence of the Mn-rich carbonate and native copper indicates that the fluid had previously been capable of leaching trace elements from basalt. This, therefore, suggests that the fluid may well have been acidic and reducing before it reached the upper part of Hole 417A. The extreme development of the chemical changes and the not unusual secondary mineralogy implies that these basalts were exposed to weathering reactions for a considerable length of time, much longer than those found in Hole 418A only $6.5 \mathrm{~km}$ away.

In Hole 418A, a different sequence of weathering can be determined. Low temperatures during weathering are again suggested by the mineralogy. The green celadonite, suggestive of a relatively high $\mathrm{Eh}$, appears to have formed first as it lines vesicles and veins. During this time, leaching of olivine phenocrysts probably occurred. This was followed by more alkaline, reducing conditions, which resulted in the precipitation of pyrite, zeolites, Fe-rich saponite, and probably chalcedony or quartz. The occurrence of calcite in filling lined vesicles and veins implies that the extensive carbonation occurred later. The final stage of weathering was the localized oxidation along cracks and breccia zones, which was responsible for the formation of limonite.

Comparing the two holes, it is evident that the oceanic crust may undergo different weathering processes, even within very short distances. Both holes are dominated by the same general type of mineralogy, i.e., clay minerals and carbonates, suggesting that they were weathered at similar temperatures. However, subtle differences in $p \mathrm{H}$, Eh, and fluid chemistry result in the formation of various minor minerals. The fluid chemistry will depend on the previous reactions in which it has taken part on its circulation path through the basaltic column. Hence, in the case of the upper part of Hole 417A, there existed an open, permeable system (much enhanced by the brecciated nature of the basalts) in which alkaline, oxidizing conditions were maintained over a very long period of time. However, as previously discussed, some aspects of the mineralogy suggest that some of the fluid entering this system was acidic and reducing. This leads to the conclusion that the upper part of Hole 417A may therefore represent an oxygenated zone of mixing of the circulating fluids and relatively unaltered sea water.

In the case of Hole 418A, the system was probably becoming sealed during weathering, hence creating different circulation paths or isolating areas of the crust from further reaction with the circulating fluid. This resulted in the evolution of the fluid composition, and hence the variation in secondary mineralogy observed in this hole. It is not surprising, therefore, that weathering has created considerable chemical differences between the closely spaced Holes 417A and 418A. This leads to the conclusion that low temperature weathering of oceanic basalts is an extremely in- 


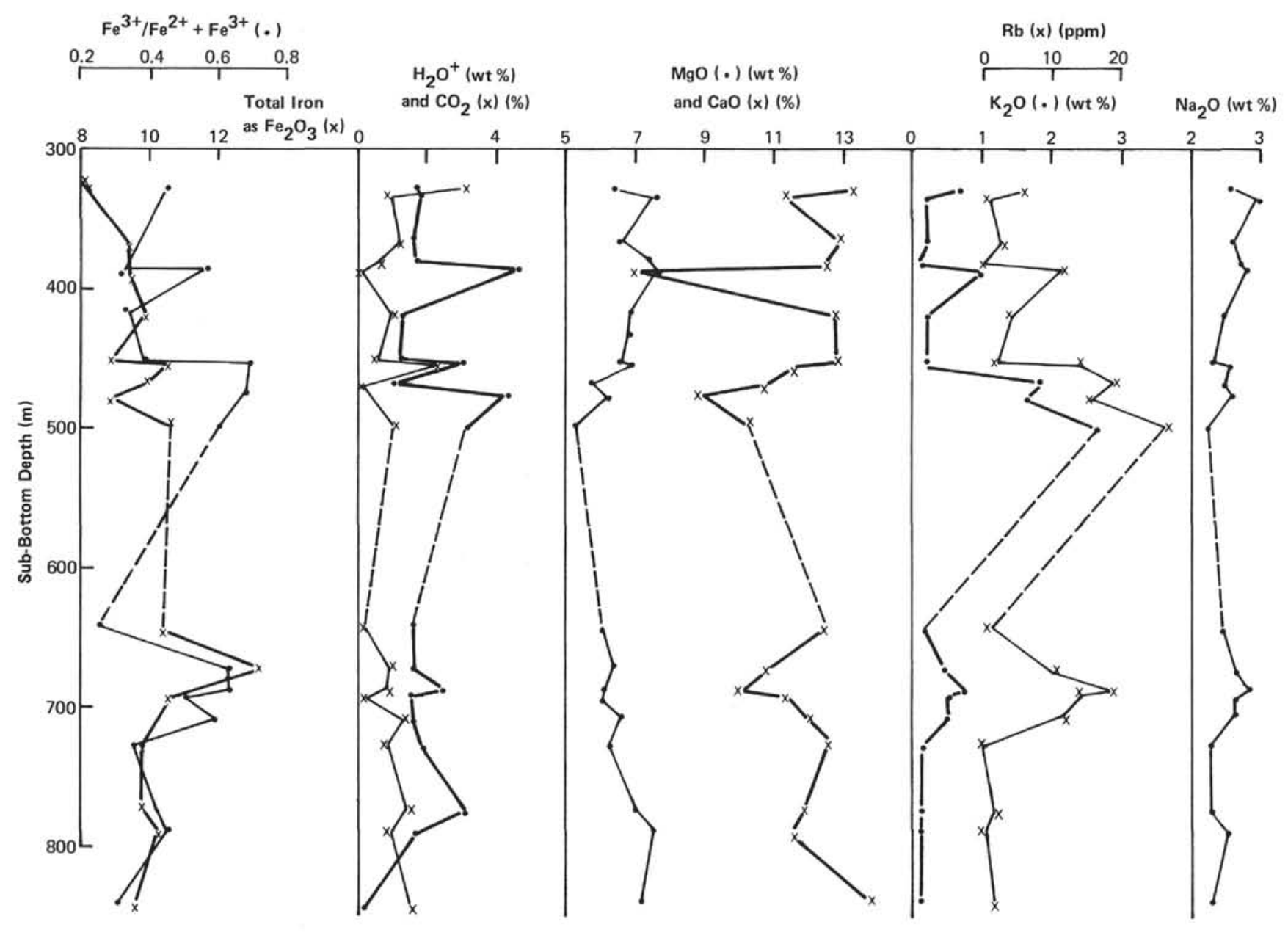

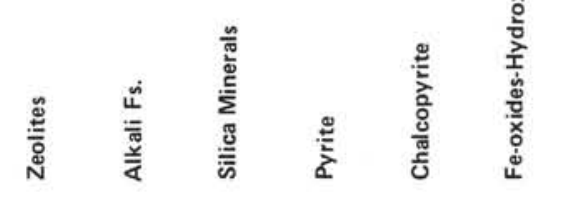

is

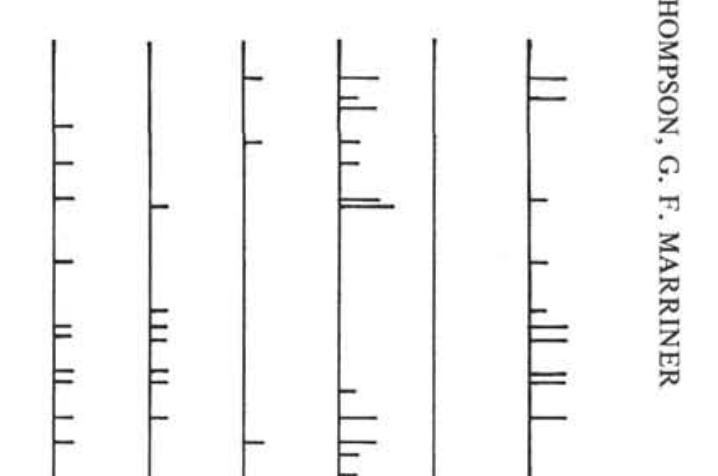

Figure 7. Downhole mineralogical and chemical variations in Hole $418 \mathrm{~A}$. 
homogeneous process, both spatially and temporally. Because of this variability, it may prove extremely difficult to estimate accurately its significance in terms of elemental fluxes and geochemical mass balances.

\section{ACKNOWLEDGMENTS}

We wish to express our thanks to Dr. J.V.P. Long for permission to use the electron microprobe at Cambridge University, and particularly to Dr. N. Charnley for assistance in its operation. We are also grateful for permission to use the $\mathrm{CHN}$ analyzer at the British Museum (Natural History). Thanks are also due to P. Watkins and R. Curtis for assistance in the laboratory, and to Dr. J.R. Lawrence for helpful criticism of this paper.

This research was supported by NERC Grant GR3/2946.

\section{REFERENCES}

Andrews A.J., Barnett, R.L., MacClement, B.A.E., Fyfe, W.S., Morrison, G., MacRae, N.D., and Starkey, J., 1977. Zeolite facies metamorphism, geochemistry, and some aspects of trace element redistribution in altered basalts of DSDP, Leg 37. In Aumento, F., Melson, W.G., et al., Initial Reports of the Deep Sea Drilling Project, v. 37: Washington (U.S. Government Printing Office), p. 795-810.

Butler, B.S. and Burbank, W.S., 1929. The copper deposits of Michigan, U.S. Geological Survey Prof. Paper 144: Washington (U.S. Government Printing Office).
Czamanske, G.K. and Moore, J.G., 1977. Composition and phase chemistry of sulfide globules in basalt from the Mid-Atlantic Ridge rift valley near $37^{\circ} \mathrm{N}$. lat, Geol. Soc. Am. Bull., v. 88 , p. 587-599.

Deer, W.A., Howie, R.A., and Zussman, J., 1962. Rock-forming minerals, v. 5: New York (J. Wiley and Sons, Inc.).

Garrels, R.M. and Christ, C.L., 1965. Solutions, minerals and equilibria: New York (Harper and Row).

Garrels, R.M. and Mackenzie, F.T., 1971. Evolution of sedimentary rocks: New York (W.W. Norton).

Li, Y-H., Bischoff, J., and Mathieu, G., 1969. The migration of Mn in the Arctic Basin sediments, Earth Planet. Sci. Lett., v. 7, p. 265-270.

Robinson, P.R., Flower, M.F.J., Schminke, H-U., and Ohnmacht, W., 1977. Low temperature alteration of oceanic basalts, DSDP, Leg 37. In Aumento, F., Melson, W.G., et al., Initial Reports of the Deep Sea Drilling Project, v.37: Washington (U.S. Government Printing Office), p. 775-793.

Scheidegger, K.F. and Stakes, D.S., 1977. Mineralogy, chemistry, and crystallization sequence of clay minerals in altered tholeiitic basalts from the Peru Trench, Earth Planet. Sci. Lett., v. 36, p. 413-422.

Thompson, G., 1973. A geochemical study of the low temperature interaction of seawater and oceanic igneous rocks, EOS, Trans. Am. Geophys. Union, v. 54, p. 1015-1019.

Whipple, E.R., 1974. A study of Wilson's determination of ferrous iron in silicates, Chem. Geol., v. 14, p. 223. 


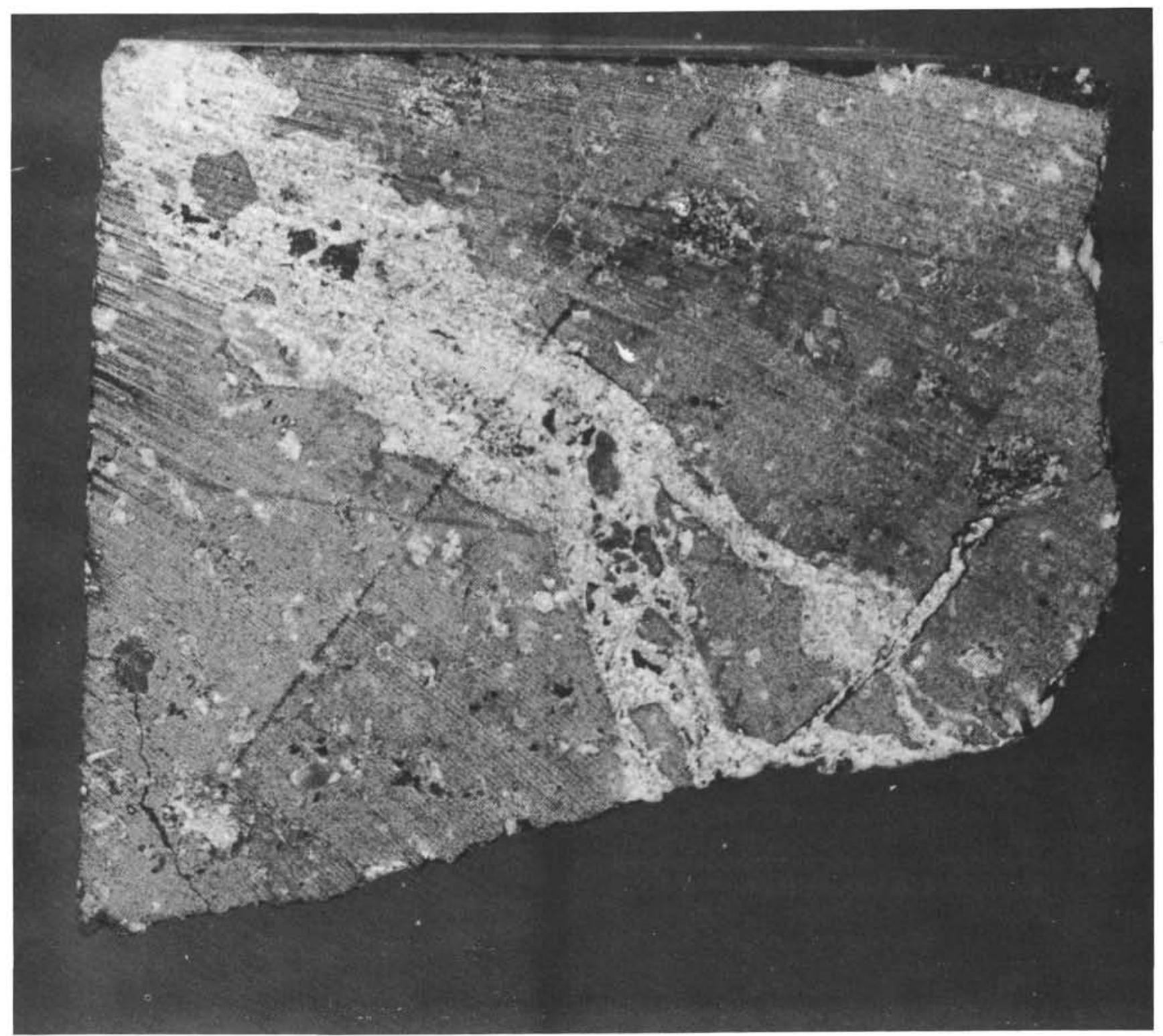

$1.0 \mathrm{~cm}$

PLATE 1

Sample 417 A-28-4, 54-57 cm. Pillow basalt showing weathered phenocrysts but relatively fresh groundmass. The large calcite vein cross-cutting the basalt contains fragments of wallrock. Minor vein shows lining of hematite with a subsequent infilling of calcite. 


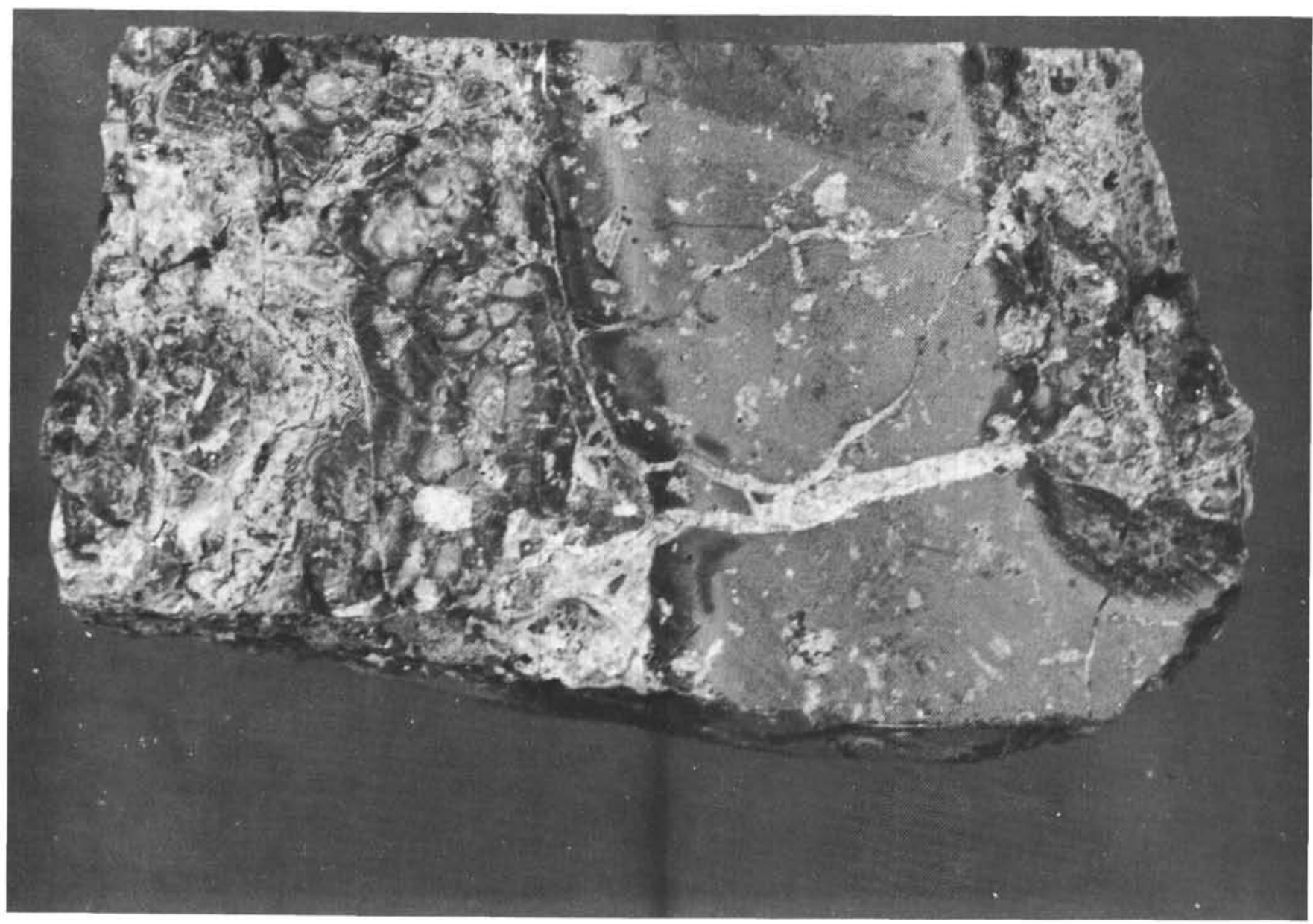

$1.0 \mathrm{~cm}$

\section{PLATE 2}

Sample 417A-26-3, 86-91 cm. Breccia consisting of a large fragment of highly weathered basalt in a matrix of calcite. Note the "agate-like", structures adjacent to the fragment of basalt. These consist of concentric, alternating bands of brown and green clay minerals. 
PLATE 3

Transmitted light photomicrographs of secondary minerals in basalts from Holes 417A and 418A.

Figure 1 Sample 417A-29-3, 136-138 cm. Weathered feldspar phenocryst, showing replacement by calcite in the center, and clay minerals along cleavages and cracks. $8 \times$.

Figure 2 Sample 418A-47-3, 42-46 cm (\#3A). Olivine phenocrysts pseudomorphed by brown iron-rich saponite. $10 \times$.

Figure 3 Sample 418A-55-6, 43-49 cm (\#3B). Zoned vesicle with wide, outer green rim, and brown interior. $40 \times$.

Figure 4 Sample 418A-60-1, 117-121 cm (\#2C). Vesicle with outer green rim and inner concentric brown smectite zones varying from light brown adjacent to the green lining to a dark brown central zone. Small red limonite vein is seen at the bottom right of the photograph. $8 \times$.

Figure 5 Sample 418A-36-2, 25-37 cm (\#2). Aggregates of radiating needle-like crystals of zeolites (phillipsite?) infilling vein. $50.5 \times$.

Figure 6 Sample 418A-16-2, 31-36 cm (\#1A). Wide, complex vein consisting of concentric bands of green and brown smectites which are infilled with calcite and iron oxides. $12.5 \times$. 
PLATE 3

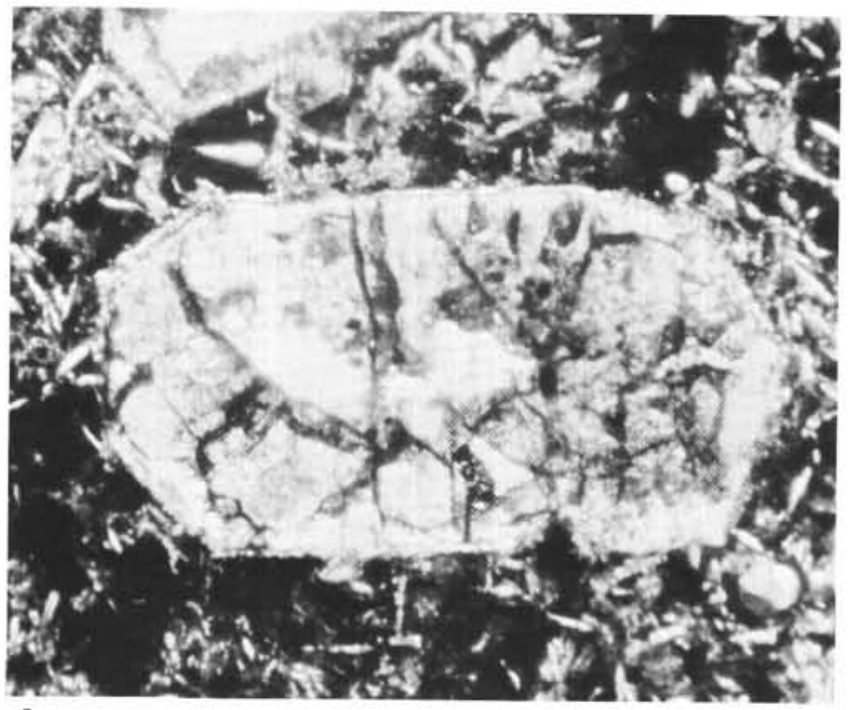
1

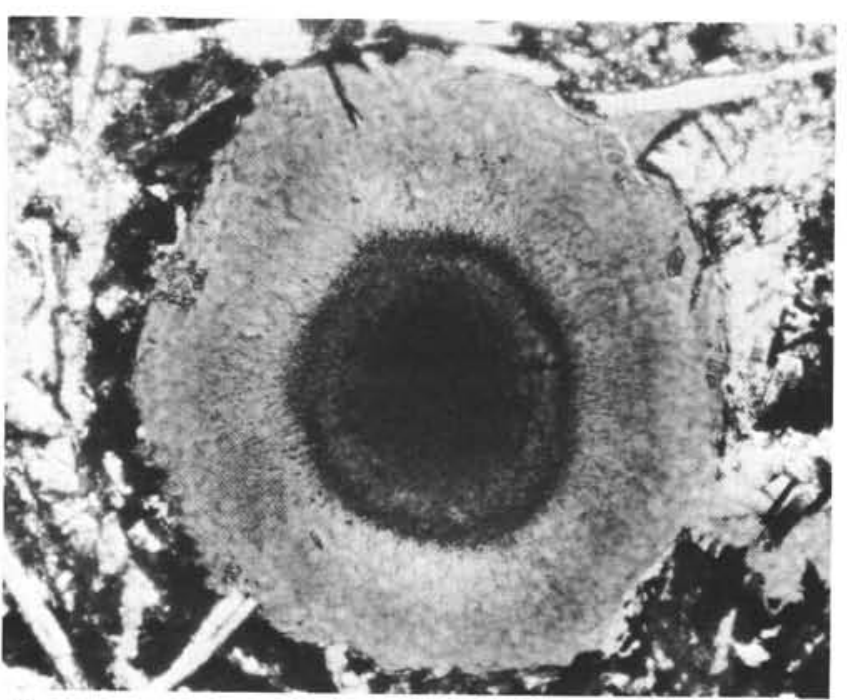

3

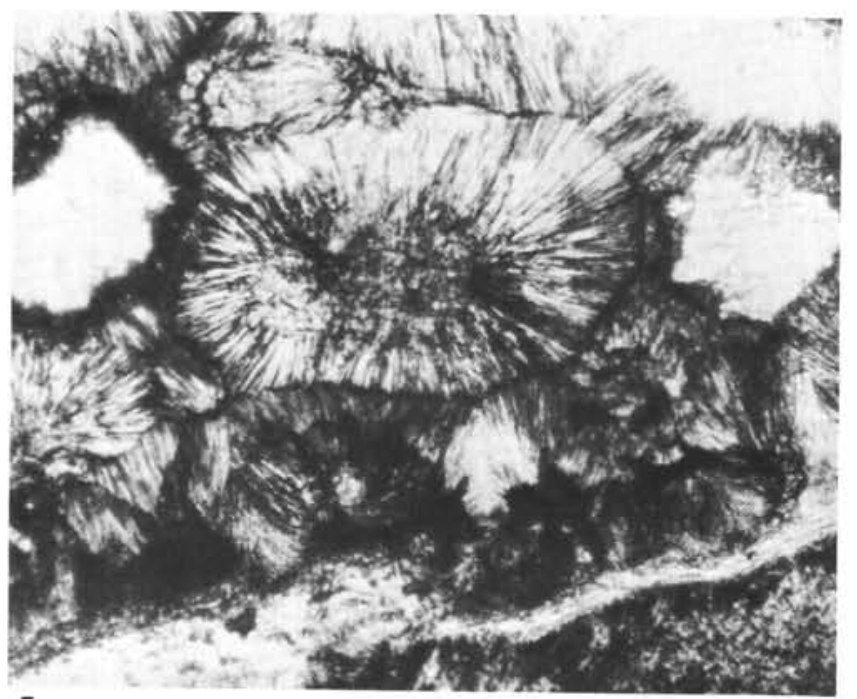

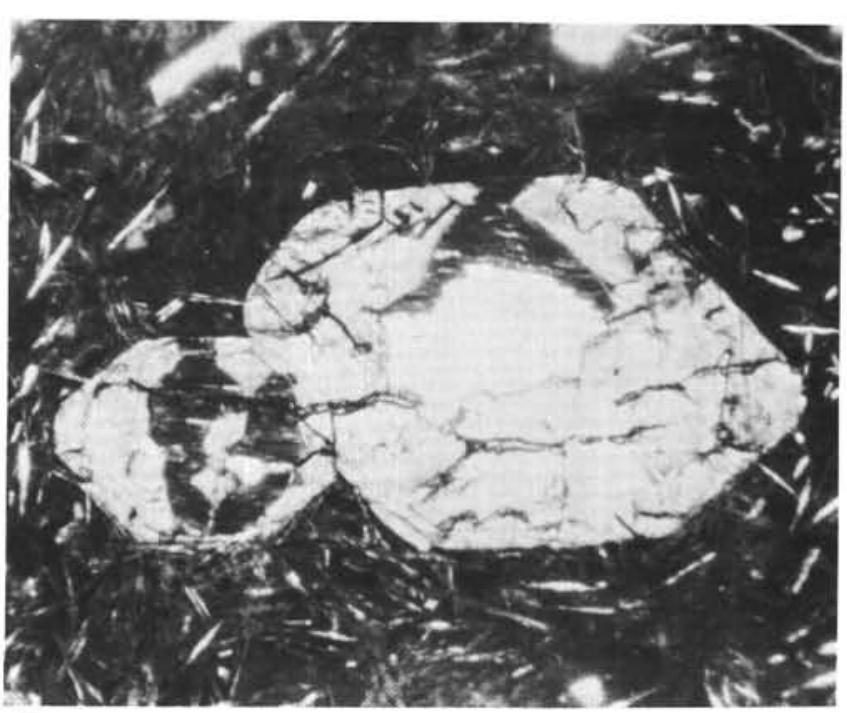

2

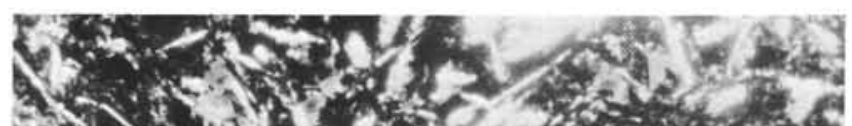

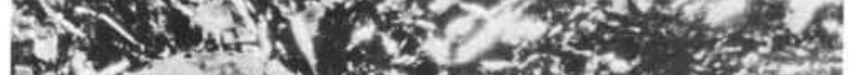

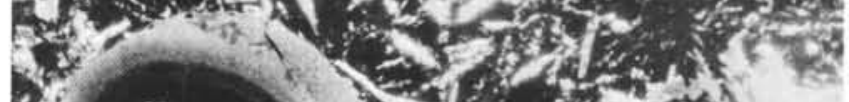

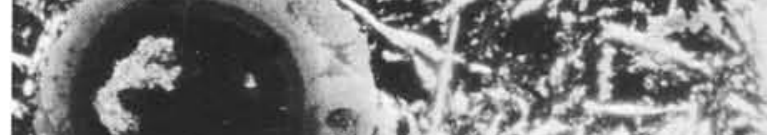
S. Wh

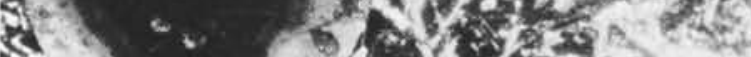

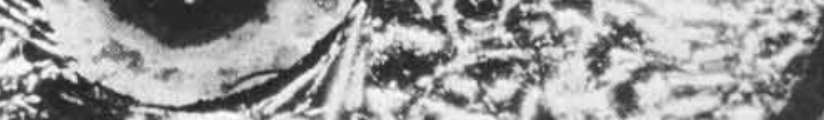

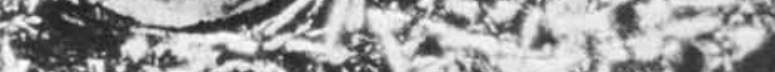
7 .

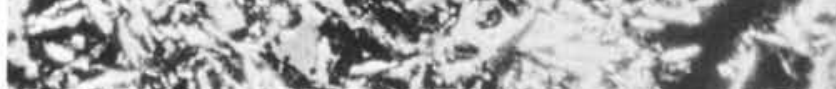

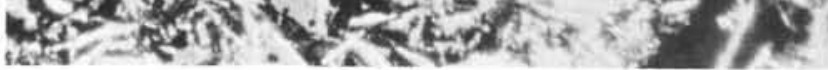
4

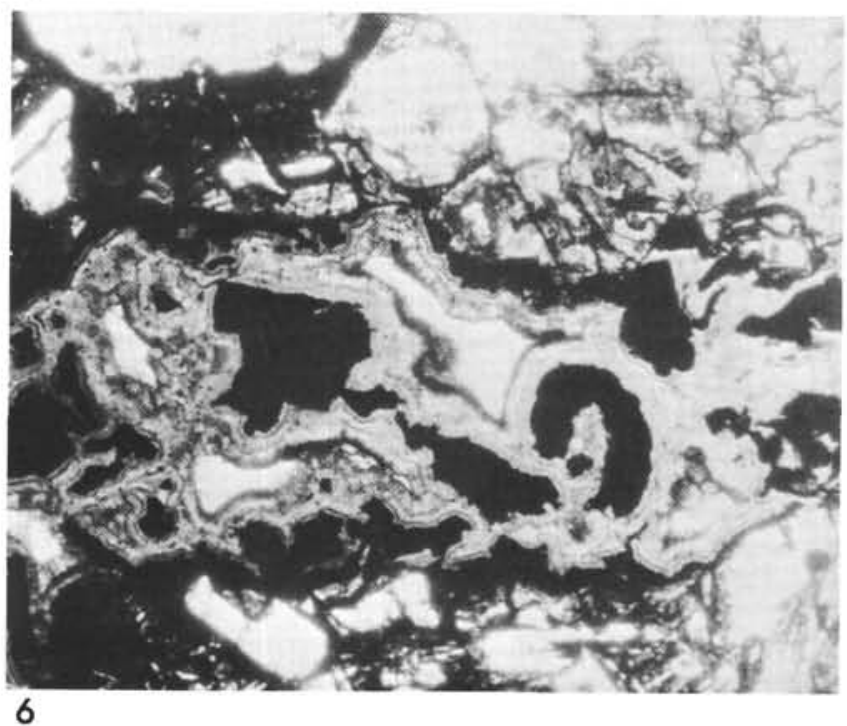

